\title{
EMU and the Stability and Volatility of Foreign Exchange: Some Empirical Evidence*
}

\author{
Mikael Bask ${ }^{\dagger}$ and Xavier de Luna ${ }^{\ddagger}$
}

October 24, 2001

\begin{abstract}
How has the European monetary integration, with the creation of the EMU, affected the stability and volatility of foreign exchange? In order to answer this question, stability and volatility measures are defined and calculated. We then use these to investigate the changes in the stability and volatility of 16 European currencies, and in the volatility of the shocks to these currencies. The stability measures are based on smooth Lyapunov exponents, while the volatility measures utilize the variances. The results indicate that when most of the currencies become more stable, the majority also become less volatile. For example, following the agreement of the Maastricht Treaty most currencies became more stable and less volatile, whereas they became less stable and more volatile when the Danish public voted against the treaty. Finally, there is no empirical support for the view that a decision to step aside from a closer monetary collaboration has a negative effect on the stability of the currency.
\end{abstract}

* An earlier version of the paper was presented at the "2nd CeNDEF Workshop on Economic Dynamics" in Amsterdam, The Netherlands, January 4-6, 2001. Earlier versions have also been presented at seminars at Stockholm University and Umeå University. Helpful comments and suggestions are gratefully acknowledged, as also is the financial support from the Jan Wallanders and Tom Hedelius Foundation.

$\dagger$ Corresponding author. Department of Economics, Umeå University, SE-901 87 Umeå, Sweden, Email: mikael.bask@econ.umu.se

‡ Department of Statistics, Umeå University, SE-901 87 Umeå, Sweden, E-mail: xavier.deluna@stat.umu.se 


\section{Introduction}

The stability and volatility of foreign exchange are different concepts, and it is important to make a clear distinction between them. Therefore, let us start by giving an example that may clarify this difference.

Since the breakdown of the Bretton Woods system in March 1973, the exchange rates have become more volatile. According to the pre-1973 advocates of flexible exchange rates, this should not be the case as a volatile exchange rate is the manifestation of volatile macroeconomic fundamentals. Friedman (1953, p. 158), in his case for flexible exchange rates, argued:

"Instability of exchange rates is a symptom of instability in the underlying economic structure."

Johnson (1970, p. 99), another pre-1973 advocate of flexible exchanges rates, wrote:

"A freely flexible exchange rate would tend to remain constant so long as underlying economic conditions (including governmental policies) remained constant."

As a first approximation, however, countries with flexible exchange rates have more volatile rates than countries with target zones, but equally volatile fundamentals (Flood and Rose, 1999). In fact, the volatility of macroeconomic fundamentals such as money and output do not change much across currency regimes (Flood and Rose, 1995). Therefore, Flood and Rose (1995, p. 5) suggest that macroeconomic fundamentals alone are unable to explain exchange rate volatility:

"Intuitively, if exchange rate stability varies across regimes without correspond-

ing variation in macroeconomic volatility, then macroeconomic variables will be unable to explain much exchange rate volatility."

However, by making a clear distinction between the volatility of an exchange rate and the stability of the dynamic system generating the exchange rate, one may resolve the apparent paradox that exchange rates have become more volatile while macroeconomic fundamentals have not. To be more specific, a volatile exchange rate may also be the 
manifestation of a less stable dynamic system and not only of volatile fundamentals. The argument runs as follows. Since macroeconomic variables, such as money and output, interact with each other through time and space, and, therefore, constitute a dynamic system, the stability of the system is crucial for the volatility of the exchange rate. A dynamic system can be said to be less stable than another system if it is more persistent in nature. Therefore, a less stable system may cause a volatile exchange rate, even if the macroeconomic fundamentals are not so volatile.

While the volatility is measured by the variance, the stability properties of a stochastic dynamic system can be described by a smooth version of the Lyapunov exponents (see Bask and de Luna, 2001, for details and a more thorough discussion). These exponents are smooth in the sense that they are defined with respect to a realization of a stochastic process, and not with respect to a trajectory generated by a deterministic system (see, e.g., Dechert and Gençay, 1992, Gençay and Dechert, 1992, and Nychka et al., 1992). The more negative the exponents are, the more stable and less persistent the system is.

On January 1, 1999, the common European currency, the Euro, was launched, thus starting the third and final stage in the creation of the Economic and Monetary Union, EMU. The project to launch a common currency was concretized through, for example, the Delors Report and the Maastricht Treaty. One motive behind the creation of the EMU was a political preference for exchange rates that are not excessively volatile, which has been revealed by the many currency regimes throughout the last hundred years. However, although fixed exchange rates have been considered as desirable, not all of the members of the European Union, EU, participate in the EMU. ${ }^{1}$ Denmark, Sweden and the United Kingdom are to date (October 2001) not members of the EMU, and Greece joined two years after its launch.

The purpose of this paper is to investigate the change in the stability and volatility of foreign exchange during the creation of the EMU, with a focus on the 1990s. To be more specific, how has the stability and volatility of European currencies been affected by political decisions and public referendums related to monetary integration? For this purpose, the dynamics of daily exchange rates for 16 European currencies are analyzed, based on data from the beginning of 1990 to the end of the first quarter of 2001. The

\footnotetext{
${ }^{1}$ The pros and cons of a membership in the EMU are outside the scope of this paper.
} 
currencies used are those for all EU member states (except the Luxembourg Franc), the Norwegian Krone and the Swiss Franc, and the rates are those against the ECU, the Euro and the U.S. Dollar.

The rest of the paper is organized as follows. Section 2 provides a historical background and describes the European monetary integration and the creation of the EMU. The theoretical and empirical frameworks are outlined in Section 3 and Section 4, respectively. Our data set is presented in Section 5 and the results are given in Section 6. Finally, Section 7 concludes the paper.

\section{The European monetary integration}

On January 1, 1999, the common European currency, the Euro, was launched. ${ }^{2}$ The idea of a closer monetary collaboration in Europe is, however, not new. In fact, the idea of a common currency can be traced back to 1464, when Georg Podiebrad suggested it in his book Tractatus. More recently, there have been several monetary arrangements aiming at achieving less volatile exchange rates. The Gold Standard, which flourished from around 1880 until 1914, is one example. Another is the Bretton Woods system, which was set up at the end of the second world war and functioned effectively as a mechanism for pegging exchange rates until the link between the gold and the U.S. Dollar was suspended in August 1971. The final breakdown of the system came in March 1973.

Turning to the European monetary integration, its modern history starts in March 1957, when the Treaty of Rome was signed and the European Economic Community, EEC, was founded. Belgium, France, Germany, Italy, Luxembourg and the Netherlands agreed in the Treaty of Rome to consider their exchange rate policies as a matter of common concern, although there was no mention in the treaty of how this would be carried out in practice.

Later, and with the erosion of the Bretton Woods system, the member states of the EEC agreed at the Hague summit in December 1969 to the formation of a European economic and monetary union. Pierre Werner, the prime minister and finance minister of Luxembourg, was appointed to chair an expert group to develop the proposal. The final

\footnotetext{
${ }^{2}$ The literature on the European monetary integration and the launch of the Euro is voluminous. This section is primarily based on Levitt and Lord (2000), and Pitchford and Cox (1997).
} 
report was produced in February 1971, and it envisaged the creation of an economic and monetary union in three stages.

Even if there was no mention of a single currency in the Werner Report, the permanent fixing of exchange rates formed the final stage in the process of creating a monetary union. The proposal was endorsed by the Paris summit in October 1972, which called for completion of the transitional stages by the end of 1980. For that purpose, a new exchange rate system was launched, the currency "snake." However, the "snake" soon ran into difficulties for several reasons, including the first oil price shock. The Werner Report plan never recovered from these difficulties, and the politicians' dream of creating an economic and monetary union was postponed.

By the late 1970s, the next step in the European monetary integration was taken. At the Bremen summit in June 1978, the French president, Valéry Giscard d'Estaing, and the German chancellor, Helmut Schmidt, launched a joint initiative for exchange rate "stabilization," which was to materialize as the European Monetary System, EMS, with the Exchange Rate Mechanism, ERM, as the principal feature of the system. The EMS started in March 1979, and has proved to be more durable than its predecessors. A new currency was also launched, the ECU, which was formed as a "basket" of the EEC currencies, weighted according to their relative share of the EEC gross national product.

An important step in the European monetary integration was taken at the Hannover summit in June 1988, when Jacques Delors, the president of the Commission, was appointed to chair a committee composed of the governors of the central banks in the EEC and a number of experts. The Delors Report came in April 1989 and envisaged, like the Werner Report 18 years earlier, the creation of an economic and monetary union in three stages. The proposal was endorsed by the Madrid summit in June 1989, and it was decided to start stage one, i.e., the completion of the internal market, in July 1990.

The Treaty of the European Union was agreed by the European Council at the Maastricht summit in December 1991. The Maastricht Treaty incorporated much of the Delors Report, even if there were some changes. In short, stage two, which started in January 1994, included amongst other things the establishment of the European Monetary Institute, EMI, the forerunner of the European Central Bank, ECB, and made the national central banks more independent of the political process. The main function of the EMI 
was to strengthen the economic and monetary collaboration between the member states of the EU. Stage three in the process, which started in January 1999, comprised the start of the EMU, i.e., a new central banking system, giving preeminence to the ECB to maintain price stability, and the launch of the Euro as the new common European currency.

However, the ratification of the Maastricht Treaty by the national parliaments ran into unexpected difficulties. In June 1992, the Danish public voted against the Maastricht Treaty. The French president, Francois Mitterand, responded the day after the Danish referendum by announcing that a similar referendum would be held in France in September the same year. The French public voted for the Maastricht Treaty, but the margin was very small. Thus, the referendums in Denmark and France revealed that the political process and public opinion were not in agreement with each other, and this was one reason for the currency turmoils that drove a number of currencies to devaluate or leave the ERM, among the latter was the British Pound. As a consequence, the finance ministers in the EEC decided in August 1993 to widen the fluctuation band considerably for all currencies except the Dutch Guilder and the German Mark. Thus, the ERM almost collapsed.

At the Madrid summit in December 1995, the European Council adopted the Commission's Green Paper on the transition to a single currency. According to the timetable, 1997 would be the crucial year for examining which countries qualified for participating in the EMU, and the decisions would be taken early in 1998. The common European currency, the Euro, also got its name at the summit.

At the Dublin summit in December 1996, the German finance minister, Theo Waigel, proposed what finally became the Stability and Growth Pact. The reason was that the German public and, more particularly, the Bundesbank, were suspicious about replacing the strong German Mark with the possibly weaker Euro. It was hoped that the Stability and Growth Pact would guarantee that the member states of the EMU had strong enough economies to give credibility to the Euro. The pact contained a number of convergence criteria that a country had to fulfil relating to the inflation rate, the long-term interest rate, the fiscal position, and the volatility of its currency's exchange rates. It was adopted by the Amsterdam summit in June 1997.

The first member states of the EMU were decided at the Brussels summit in May 1998. Denmark and the United Kingdom had the right to choose whether or not to participate 
in the EMU, even if they met the convergence criteria. They decided to postpone their membership. Greece and Sweden did not qualify for membership. However, Sweden would have been allowed to participate in the EMU if it had wanted to, but it decided to defer membership. Two years after the launch of the Euro, Greece qualified for membership of the EMU. Thus, today (October 2001) a total of 12 countries participate in the EMU. They are Austria, Belgium, Finland, France, Germany, Greece, Ireland, Italy, Luxembourg, the Netherlands, Portugal and Spain.

\section{Theoretical framework}

In the first subsection, we briefly define the concept of the stability of a stochastic dynamic system utilizing a smooth version of the Lyapunov exponents. We also define, in the second subsection, measures of the changes in the stability and volatility of foreign exchange based on these exponents. Moreover, we define measures of the change in the volatility of the shocks to foreign exchange.

\subsection{Stability of a stochastic dynamic system}

Given the stochastic dynamic system

$$
x_{t}=f\left(x_{t-1}, \ldots, x_{t-p} ; \boldsymbol{\theta}\right)+\varepsilon_{t},
$$

where $\boldsymbol{\theta}$ is a parameter vector, and $\left\{\varepsilon_{t}\right\}$ is an independent process with mean zero and finite variance, we define stability as the effect of an exogenous shock on the evolution of the observed trajectory, $\left\{x_{t}\right\}$. Smooth Lyapunov exponents provide a measure of such an effect, and are, therefore, natural quantities to describe a concept of stability (Bask and de Luna, 2001).

In order to define these Lyapunov exponents, let us first define the map from $\mathbb{R}^{p}$ to $\mathbb{R}^{p}:$

$$
\begin{array}{r}
\mathbf{f}_{\boldsymbol{\theta}}: \mathbf{x}_{t-1} \rightarrow \mathbf{x}_{t} \\
=F\left(\mathbf{x}_{t-1} ; \boldsymbol{\theta}\right)
\end{array}
$$




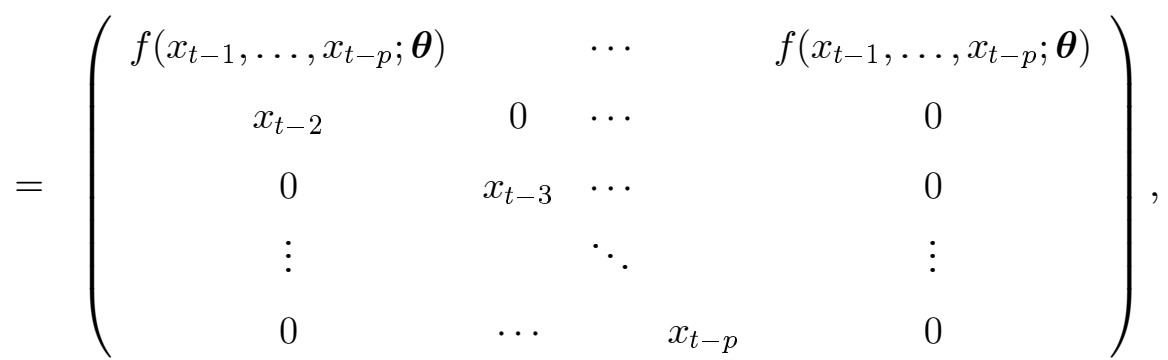

where $\mathbf{x}_{t-1}=\left[x_{t-1}, \ldots, x_{t-p}\right]^{\prime}$. We will use the Jacobian matrix $D f(\mathbf{x} ; \boldsymbol{\theta})$, which contains the partial derivatives of $F$ with respect to $\mathbf{x}_{t-1}$ evaluated at $\mathbf{x}$. Given the dynamic system in (1), there are $p$ smooth Lyapunov exponents:

$$
\bar{\lambda}_{i}=\lim _{t \rightarrow \infty} \frac{1}{t} \ln \left|\delta_{i}\left(t, \mathbf{x}_{1} ; \boldsymbol{\theta}\right)\right|, \quad i=1, \ldots, p,
$$

where $\delta_{i}\left(t, \mathbf{x}_{1} ; \boldsymbol{\theta}\right)$ are the eigenvalues of $D f\left(\mathbf{x}_{t-1} ; \boldsymbol{\theta}\right) D f\left(\mathbf{x}_{t-2} ; \boldsymbol{\theta}\right) \cdots D f\left(\mathbf{x}_{1} ; \boldsymbol{\theta}\right)$ such that $\delta_{1} \geq \delta_{2} \geq \cdots \geq \delta_{p}$. For $p=1$, the smooth Lyapunov exponent becomes

$$
\bar{\lambda}_{1}=\lim _{t \rightarrow \infty} \frac{1}{t} \sum_{i=0}^{t-1} \ln \left|\frac{d}{d x} f\left(x_{i} ; \boldsymbol{\theta}\right)\right| .
$$

The Lyapunov exponents we utilize are a smooth version of the Lyapunov exponents for deterministic dynamic systems, in the sense that they are defined with respect to a realization of a stochastic process, and not with respect to a trajectory generated by a deterministic system (see, e.g., Dechert and Gençay, 1992, Gençay and Dechert, 1992, and Nychka et al., 1992). In other words, the smooth Lyapunov exponents are defined with respect to the measure corresponding to the stochastic process admitting the representation in (1), while the Lyapunov exponents are defined with respect to the measure induced by the deterministic skeleton, $f(\cdot ; \boldsymbol{\theta})$, in $(1)$.

The reason why smooth Lyapunov exponents provide a measure of stability may be seen by considering two different starting values, where the difference is an exogenous shock to the system at time $t=0$. The largest smooth Lyapunov exponent, $\bar{\lambda}_{1}$, can be shown to be the slowest exponential rate of convergence of two trajectories of the stochastic dynamic system starting at these two different values, but with identical exogenous shocks at times $t>0$ (see, e.g., Bask and de Luna, 2001). ${ }^{3}$ In particular, when $\bar{\lambda}_{1}>0$, the trajectories diverge from each other, and for a bounded stochastic dynamic system

\footnotetext{
${ }^{3}$ Indeed, $\bar{\lambda}_{1}$ describes the convergence of a shock in the direction given by the eigenvector corresponding to $\bar{\lambda}_{1}$. If the difference between the two starting values lies in another direction of $\mathbb{R}^{p}$, then the convergence will be faster. The value of $\bar{\lambda}_{1}$ describes the worst possible case scenario.
} 
such a positive smooth Lyapunov exponent yields an operational definition of chaos. Furthermore, $\widetilde{\lambda}=\frac{1}{p} \sum_{i=1}^{p} \bar{\lambda}_{i}$ yields the exponential rate of convergence of an (geometrical) average direction, i.e., the convergence of two trajectories after a shock to the system in this average direction. ${ }^{4}$ We can, therefore, compare the stability of stochastic dynamic systems via the smooth Lyapunov exponents. For example, if two systems have a negative largest smooth Lyapunov exponent, then the larger exponent corresponds to the less stable system.

The stability properties have also a direct influence on the volatility of the stochastic dynamic system, $\operatorname{Var}\left(x_{t}\right)$. Intuitively, a shock at time $t=0$ has an effect at times $t>0$ (when the smooth Lyapunov exponents are finite), and, therefore, this shock contributes to the volatility of $x_{t}$ at times $t>0$. To date, however, there is no explicit formulation of the dependence of the volatility on the stability properties (see the discussion in Bask and de Luna, 2001, Sec. 3.2), except for linear models. For instance, when $f\left(x_{t-1}, \ldots, x_{t-p} ; \theta\right)=$ $\theta x_{t-1},|\theta|<1$, we have

$$
\operatorname{Var}\left(x_{t}\right)=\frac{\operatorname{Var}\left(\varepsilon_{t}\right)}{1-\left[\exp \left(\bar{\lambda}_{1}\right)\right]^{2}} .
$$

For such a model, the volatility of $x_{t}$ increases when either $\operatorname{Var}\left(\varepsilon_{t}\right)$, the conditional volatility, increases or the system become less stable, i.e., $\bar{\lambda}_{1}$ tends to zero. For non-linear systems, the smooth Lyapunov exponents will typically depend on the distribution of $\left\{\varepsilon_{t}\right\}$, and hence on $\operatorname{Var}\left(\varepsilon_{t}\right)$. As a consequence, the dependence of the volatility on the stability properties and on the conditional volatility is not transparent.

\subsection{Stability and volatility of foreign exchange}

Strictly speaking, a currency cannot be more or less stable (or volatile), nor can the exchange rates for the currency. Instead, the concept of stability refers to the stochastic dynamic systems generating the exchange rates for the currency. However, one may loosely define a currency as more stable than another currency if most of its exchange rates are generated by dynamic systems that are more stable.

Even though there are many exchange rates for a currency, it is reasonable to investigate only the most important ones. Having the European monetary integration in mind, the stability of the European currencies are in focus. Accordingly, we use the rates against

\footnotetext{
4 Here, the geometrical average of the directions defined by the eigenvectors corresponding to the different Lyapunov exponents.
} 
the ECU and the Euro. This is because the ECU was formed as a "basket" of the EEC currencies, and, therefore, in some sense represents all the currencies in the monetary integration. We also use the rates against the U.S. Dollar in the empirical investigations. This is because we want to control for changes in the stability (or volatility) in the rates against the U.S. Dollar as it is the most important currency in the world.

The stability measures we use are the weak change in stability and the strong change in stability. Both measures are based on the largest smooth Lyapunov exponent, $\bar{\lambda}_{1}$, and the (geometrical) average of the smooth Lyapunov exponents, $\widetilde{\lambda}=\frac{1}{p} \sum_{i=1}^{p} \bar{\lambda}_{i}$.

If $\bar{\lambda}_{1}$ (or $\tilde{\lambda}$ ) has become smaller, i.e., more negative for a non-chaotic dynamic system, then we say that the system is more stable in the current time period than in the previous one. ${ }^{5}$ More precisely, we define the absolute change in the stability of the dynamic system generating exchange rate $e$ as

$$
s_{a}^{e}=\frac{\lambda_{k}^{e}}{\lambda_{k-1}^{e}}
$$

where $\lambda$ is either $\bar{\lambda}_{1}$ or $\widetilde{\lambda}$, and $k$ is the time period. Then, the dynamic system has become absolutely more stable if $\left|s_{a}^{e}\right|>1$. Moreover, let

$$
s^{e_{1} e_{2}}=\frac{s_{a}^{e_{1}}}{s_{a}^{e_{2}}}=\frac{\lambda_{k}^{e_{1}} / \lambda_{k-1}^{e_{1}}}{\lambda_{k}^{e_{2}} / \lambda_{k-1}^{e_{2}}}
$$

where, in this paper, $e_{1}$ is the rate against the ECU (or the Euro), and $e_{2}$ is the rate against the U.S. Dollar. If $\left|s^{e_{1} e_{2}}\right|>1$, we define the currency with exchange rates $e_{1}$ and $e_{2}$ as weakly more stable. If, moreover, $\left|s_{a}^{e_{1}}\right|>1$ and $\left|s_{a}^{e_{2}}\right|>1$, the currency is defined as strongly more stable.

The volatility measures we use are the weak and strong change in the volatility of the currency, and the weak and strong change in the volatility of the shocks to the currency. These measures are defined in an analogous way as in (2), where $\lambda$ is replaced by $\operatorname{Var}\left(x_{t}\right)$ and $\operatorname{Var}\left(\varepsilon_{t}\right)$, respectively.

\section{Empirical framework}

The first subsection contains a description of the time series models used, while the second subsection shows how to estimate the smooth Lyapunov exponents from these models.

\footnotetext{
${ }^{5}$ By a time period we mean a period of several days. In this paper, a time period ranges from 57 to 866 days.
} 


\subsection{Time series models}

Let $\left(x_{1}, x_{2}, \ldots, x_{n}\right)$ be a real-valued daily time series, observed within a period of $n$ days. Let $t_{0}=0<t_{1}<\ldots<t_{m}<t_{m+1}=n$ be $m$ fixed time points at which important changes in the dynamics generating the observations might have occurred. We want to allow for drastic changes in the dynamics and stochastics between different regimes, and, therefore, analyze the $m+1$ time series $\left(x_{t_{i}+1}, \ldots, x_{t_{i+1}}\right), i=0, \ldots, m$, independently of each other.

The data generating stochastic dynamic system is modelled as a non-linear autoregression:

$$
x_{t}=f_{i}\left(x_{t-1}, \ldots, x_{t-p}\right)+\varepsilon_{t}, \quad t=t_{i}, \ldots, t_{i+1}-1, \quad i=0, \ldots, m,
$$

consisting of a deterministic skeleton (also called the dynamics), $f_{i}(\cdot)$, which is a realvalued function of $p$ lagged values of the time series, and a dynamic noise component (also called the stochastics), here an independently distributed stochastic process, $\left\{\varepsilon_{t}\right\}$.

In the particular application of interest, the time series have a low signal-to-noise ratio, and this, together with the number of available observations, has important implications at the statistical modelling stage. One such issue is the danger of overfitting, i.e., finding spurious dynamics by "fitting pure noise." A solution to circumvent this problem is to restrict oneself to non-linear dynamics whose parametrization does not explode with the number of past lags included.

With these concerns in mind, we use the models proposed and studied in de Luna (1998):

$$
f\left(x_{t-1}, \ldots, x_{t-p}\right)=\alpha_{0}+\sum_{i=1}^{d} \alpha_{i}\left(\theta_{1} x_{t-1}+\cdots+\theta_{p} x_{t-p}\right)^{i} .
$$

These are basically restricted neural networks, where only one projection of the input space, i.e., the hidden unit, is considered. This restriction guarantees a certain parsimony in the parametrization, while better flexibility in the hidden unit, than with conventional neural networks, is allowed for by using a polynomial activation function. These models are thought to be flexible enough to capture departures from linearity in the dynamics of the time series analyzed in the paper. ${ }^{6}$

\footnotetext{
${ }^{6}$ Polynomial autoregressions have often been discarded in the time series literature as being unrealistic models because of their explosive behavior outside their basin of attraction. However, they have recently been advocated in the study of the dynamics of stochastic systems in Chan and Tong (1994), and for predictive purposes in de Luna (1998).
} 


\subsection{Estimation}

For a given model structure $p$ and $d$, the parameters $\alpha_{i}, i=0, \ldots, d$, and $\theta_{i}, i=1, \ldots, p$, in (3) are consistently estimated by least squares under fairly mild assumptions about the generating stochastic process (de Luna, 1998). However, the structure of the model to be fitted needs to be identified, i.e., $p$ and $d$ have to be estimated from the data. This is a model selection issue and several criteria are available. We have chosen to work with AIC (Akaike Information Criterion) developed by Akaike (1974), which basically consists of the likelihood penalized for model complexity. More precisely, the model selected minimizes

$$
A I C(p, d)=-\log \widehat{\sigma}^{2}+2(p+d+1)
$$

where $\widehat{\sigma}^{2}$ is a consistent estimate of $\sigma^{2}$, the variance of $\varepsilon_{t}$. In the empirical investigations, we limit the identification procedure to $p \leq 7$ and $d \leq 3$. Thus, we assume that new information is incorporated in the exchange rates at worst seven days later.

The estimator of the smooth Lyapunov exponents for the order $p>1$ case is

$$
\widehat{\bar{\lambda}}_{i}=\frac{1}{m} \ln \left|\delta_{i}\left(m, \mathbf{x}_{1} ; \widehat{\boldsymbol{\theta}}\right)\right|, \quad i=1, \ldots, p,
$$

and the estimator for the order $p=1$ case is

$$
\widehat{\bar{\lambda}}=\frac{1}{m} \sum_{i=1}^{m} \ln \left|\frac{d}{d x} f\left(x_{i} ; \widehat{\boldsymbol{\theta}}\right)\right|,
$$

where in both cases a sub-sample $\mathbf{x}_{1}, \ldots, \mathbf{x}_{m}$ (in the same time order as in the original sample) of size $m \leq n$ is used. In particular, $\delta_{i}\left(m, \mathbf{x}_{1} ; \widehat{\boldsymbol{\theta}}\right)$ in (4) are the eigenvalues of $D f\left(\mathbf{x}_{m} ; \widehat{\boldsymbol{\theta}}\right) D f\left(\mathbf{x}_{m-1} ; \widehat{\boldsymbol{\theta}}\right) \cdots D f\left(\mathbf{x}_{1} ; \widehat{\boldsymbol{\theta}}\right)$. The consistency and asymptotic normality of $\widehat{\bar{\lambda}}_{1}$ and $\widehat{\bar{\lambda}}$ can be proved under certain regularity conditions (Bask and de Luna, 2001). ${ }^{7}$ Such theoretical results for the entire spectrum of Lyapunov exponents are still missing.

Note that in this paper, we only report point estimates, because of the difficulty implied in computing confidence intervals. ${ }^{8}$ On the other hand, since we consider as many as 16 currencies in the empirical investigations, we can try to find systematic patterns in the changes in the stability and volatility of foreign exchange.

\footnotetext{
${ }^{7}$ These conditions are stronger if $m=n$ is used. However, simulation results tend to indicate that $m=n$ may be used fairly generally, see Bask and de Luna (2001), McCaffrey et al. (1992), and Whang and Linton (1999).

${ }^{8}$ In Bask and de Luna (2001), confidence intervals were computed for a special case with a bootstrap procedure.
} 


\section{Data}

We use daily exchange rate data, from the beginning of 1990 to the end of the first quarter of 2001. The currencies under scrutiny can be grouped as follows: (1) all currencies for countries participating in the EMU (except the Luxembourg Franc); (2) all currencies for countries not participating in the EMU, but members of the EU; and (3) currencies for two European countries who are not members of the EU, the Norwegian Krone and the Swiss Franc. Moreover, since the stability and volatility measures used herein utilize the ECU, the Euro and the U.S. Dollar, these currencies are also included in the data set.

The exchange rate data are divided into several time series, where the breakpoints are important dates during the European monetary integration process, e.g., political decisions and public referendums. These dates are divided into two categories, where the first category consists of dates that are important for the EEC/EU as a whole, and the second of dates that are important for a specific country.

In order to ensure that the time series are stationary, we take the first difference of the (natural) logarithm of the exchange rates. The data set consists of 122257 observations, which are divided into 293 exchange rate series, ranging from 57 to 866 observations each. The data set is collected from OANDA. ${ }^{9}$

\section{Results}

A summary of the results can be found in Tables I-VIII. ${ }^{10}$ Therein, we find the change in the stability of the currencies in the first four tables, the change in the volatility of the currencies in the next two tables, and the change in the volatility of the exogenous shocks to the currencies in the last two tables. As already stated, care has to be exercised in interpreting the results in the tables as these are based on point estimates of the smooth Lyapunov exponents and the volatility terms.

Looking at the general pattern of the change in the stability and the change in the

\footnotetext{
${ }^{9}$ http://www.oanda.com/convert/fxhistory

${ }^{10}$ More detailed results can be found in Tables IX-XL, where we present, for all 293 exchange rate series, the cumulative sum of the Lyapunov exponents, the volatility of the exchange rate and the exogenous shocks to the rate, the explained volatility, the number of observations, and the degree of the polynomial autoregression fitted to the data. The weak change in the stability (both utilizing the largest and the average Lyapunov exponent) and volatility for all 16 currencies, and the weak change in the volatility of the exogenous shocks to these currencies are also provided.
} 
volatility (both of the currencies and the shocks), there are two striking results. Firstly, when the shocks to most of the currencies have become more (less) volatile, a majority of the currencies have also become more (less) volatile. Secondly, when most of the currencies have become more (less) stable, the volatility (both of the currencies and the shocks) has decreased (increased). These results may not be too surprising as the stability properties of a dynamic system and the volatilities are related, even if not in a transparent way for non-linear systems (see the discussion in Sec. 3.1).

Focusing on specific events in the European monetary integration process (cf., Tables I-II, V and VII), and the relation between the stability and volatility of foreign exchange, 15 currencies became more stable (cf., Table I which is based on estimates of the largest Lyapunov exponent) and 12 currencies became less volatile, when the Maastricht Treaty was agreed upon in December 1991. When the Danish public, in a referendum in June 1992, voted against the Maastricht Treaty, the effects on the stability and volatility of foreign exchange were even more striking, as 13 currencies became less stable while all 16 currencies became more volatile. However, when it comes to the other events that are important for the EEC/EU as a whole, the results are not as clear.

The widening of the fluctuation bands within the ERM in August 1993, ended the currency turmoils that had started with the referendums in Denmark and France. In practice, most of the countries that participated in the ERM changed their currency regime, from fixed to flexible exchange rates. This had, however, an inconclusive effect on the stability and volatility of the foreign exchange. The Madrid summit in December 1995, with the adoption of the Commission's Green Paper, also had an inconclusive effect, even if a weak majority of the currencies became less stable and more volatile. Turning to the Amsterdam summit in June 1997, and the adoption of the Stability and Growth Pact, 11 currencies became more stable and 15 currencies less volatile. Finally, a weak majority of the currencies became less stable and more volatile after the Brussel summit in May 1998, where the first member states of the EMU were decided.

There is no empirical support for the view that a decision to step aside from a closer monetary collaboration has a negative effect on the stability of the currency. This result is interesting since it has sometimes been claimed in the political debate that the currencies for EU countries outside the EMU have become less "stable" during the monetary 
integration process. ${ }^{11}$ On the contrary, it seems that most of the currencies have become more stable, e.g., when the link to the ECU has been severed, when a currency no longer participate in the ERM, or when the public has voted against membership of the EMU.

\section{Discussion}

At the heart of this paper, a clear distinction has been made between the stability and volatility of foreign exchange, and the volatility of exogenous shocks to the currencies. To be more specific, we have emphasized the difference between the volatility of an exchange rate and the stability of the dynamic system generating the exchange rate. Based on this distinction, stability measures of foreign exchange have been defined that utilize a smooth version of the Lyapunov exponents, while the volatility measures have used variances in their definitions.

The empirical investigations revealed a strong positive correlation between the volatility of the currencies and the volatility of the shocks to the currencies, while a negative correlation was found between the stability of the currencies and the volatility measures. Turning to specific events, the agreement upon the Maastricht Treaty made most of the currencies more stable and less volatile, while most of the currencies became less stable and more volatile when the Danish public voted against the treaty. Finally, there is no empirical support for the view that a decision to step aside from a closer monetary collaboration has a negative effect on the stability of the currency.

Although strong correlations between the stability and volatility measures have been observed in this paper, it is hoped that new insights will be gained by making a clear distinction between the concepts. Thus, the focus in the empirical research should not only be on the volatility of exchange rates, but also on the stability of the dynamic systems generating these rates.

A more thorough discussion of the economic mechanisms behind these empirical observations is not possible since we do not have an economic model that explicitly addresses the relationship between the stability and volatility of foreign exchange. However, we think that a good starting point for such a model is the literature on heterogenous agents,

\footnotetext{
${ }^{11}$ This point of view has, of course, its origin in the confusion between the concepts of the stability and volatility of foreign exchange.
} 
specifically on adaptive belief systems (Brock and Hommes, 1997). Basically, these models assumes that there are different groups of agents following different self-fulfilling expectations and trading strategies. The dynamics of these models have been proven to be rich, including an irregular switching between a stable phase of low volatility and an unstable phase of high volatility. ${ }^{12}$ To date, models based on adaptive belief systems have been applied to asset pricing only. Their application to foreign exchange mechanisms are a matter for future research.

\section{References}

Akaike, H. (1974). A new look at the statistical model identification. IEEE Transactions on Automatic Control, 19, 716-723.

Bask, M. and de Luna, X. (2001). Characterizing the degree of stability of non-linear dynamic models. Umeå Economic Studies No. 564.

Brock, W. A. and Hommes, C. H. (1997). A rational route to randomness. Econometrica, 65, 1059-1095.

Chan, K. S. and Tong, H. (1994). A note on noisy chaos. Journal of the Royal Statistical Society, B56, 301-311.

Dechert, W. D. and Gençay, R. (1992). Lyapunov exponents as a nonparametric diagnostic for stability analysis. Journal of Applied Econometrics, 7, S41-S60.

Flood, R. P. and Rose, A. K. (1995). Fixing exchange rates: A virtual quest for fundamentals. Journal of Monetary Economics, 36, 3-37.

Flood, R. P. and Rose, A. K. (1999). Understanding exchange rate volatility without the contrivance of macroeconomics. Economic Journal, 109, F660-F672.

Friedman, M. (1953). The case for flexible exchange rates. In Essays in positive economics. Chicago: Chicago University Press.

Gençay, R. and Dechert, W. D. (1992). An algorithm for the $n$ Lyapunov exponents of an n-dimensional unknown dynamical system. Physica D, 59, 142-157.

Hommes, C. H. (2001). Financial markets as nonlinear adaptive evolutionary systems. Quantitative Finance, 1, 149-167.

\footnotetext{
12 A nice introduction to this research area can be found in Hommes (2001).
} 
Johnson, H. G. (1970). The case for flexible exchange rates, 1969. In Approaches to greater flexibility of exchange rates: The Bürgenstock papers, ed. by Halm, G. N. Princeton: Princeton University Press.

Levitt, M. and Lord, C. (2000). The political economy of monetary union. London: Macmillan Press.

de Luna, X. (1998). Projected polynomial autoregression for prediction of stationary time series. Journal of Applied Statistics, 25, 763-775.

McCaffrey, D., Ellner, S., Gallant, A.R. and Nychka, D. (1992). Estimating the Lyapunov exponent of a chaotic system with nonparametric regression. Journal of the American Statistical Association, 87, 682-695.

Nychka, D., Ellner, S., Gallant, A. R. and McCaffrey, D. (1992). Finding chaos in noisy systems. Journal of the Royal Statistical Society, B54, 399-426.

Pitchford, R. and Cox, A. (1997). EMU explained: Markets and monetary union. London: Reuters.

Whang, Y.-J. and Linton, O. (1999). The asymptotic distribution of nonparametric estimates of the Lyapunov exponent for stochastic time series. Journal of Econometrics, 91, 1-42. 
Table I: The change in the stability of the currencies (utilizing the largest Lyapunov exponent) at dates that are important for the EEC/EU as a whole

\begin{tabular}{|c|c|c|c|c|c|c|}
\hline \multirow{2}{*}{$\begin{array}{l}\text { Event } \\
\begin{array}{c}\text { The Maastricht Treaty is agreed upon } \\
(91 / 10 / 12)\end{array}\end{array}$} & \multicolumn{3}{|c|}{ Weakly more stable } & \multicolumn{3}{|c|}{ Weakly less stable } \\
\hline & $\begin{array}{l}\text { ATS* } \\
\text { FIM** }^{* *} \\
\text { IEP } \\
\text { ESP } \\
\text { GRD* }\end{array}$ & $\begin{array}{l}\text { BEF } \\
\text { FRF } \\
\text { ITL } \\
\text { GBP } \\
\text { NOK }^{* *}\end{array}$ & $\begin{array}{l}\text { NLG } \\
\text { DEM } \\
\text { PTE* }^{*} \\
\text { DKK } \\
\text { CHF* }^{*}\end{array}$ & SEK $^{* *}$ & & \\
\hline $\begin{array}{l}\text { The Danish public votes against the } \\
\text { Maastricht Treaty } \\
(92 / 02 / 06)\end{array}$ & NLG & IEP & ESP & $\begin{array}{l}\text { ATS }^{*} \\
\text { FRF } \\
\text { PTE } \\
\text { GRD }^{*} \\
\text { CHF }^{*}\end{array}$ & $\begin{array}{l}\text { BEF } \\
\text { DEM } \\
\text { GBP } \\
\text { SEK }^{* *}\end{array}$ & $\begin{array}{l}\text { FIM }^{* *} \\
\text { ITL } \\
\text { DKK } \\
\text { NOK }^{* *}\end{array}$ \\
\hline $\begin{array}{l}\text { The fluctuation bands within the ERM } \\
\text { are widened considerably } \\
(93 / 02 / 08)\end{array}$ & $\begin{array}{l}\text { ATS* }^{*} \\
\text { FRF } \\
\text { GRD* }^{*}\end{array}$ & $\begin{array}{l}\text { BEF } \\
\text { DEM } \\
\text { SEK* }^{*}\end{array}$ & $\begin{array}{l}\text { FIM* }^{*} \\
\text { PTE } \\
\text { NOK* }^{*}\end{array}$ & $\begin{array}{l}\text { NLG } \\
\text { ESP } \\
\text { CHF* }^{*}\end{array}$ & $\begin{array}{l}\text { IEP } \\
\mathrm{GBP}^{*}\end{array}$ & $\begin{array}{l}\text { ITL* } \\
\text { DKK }\end{array}$ \\
\hline $\begin{array}{l}\text { The Madrid summit adopts the } \\
\text { Commission's Green Paper } \\
(95 / 16 / 12)\end{array}$ & $\begin{array}{l}\text { DEM } \\
\text { GRD* }^{*}\end{array}$ & $\begin{array}{l}\text { IEP } \\
\mathrm{CHF}^{*}\end{array}$ & ESP & $\begin{array}{l}\text { ATS } \\
\text { FIM* }^{*} \\
\text { PTE } \\
\text { SEK }^{*}\end{array}$ & $\begin{array}{l}\text { BEF } \\
\text { FRF } \\
\text { GBP }^{*} \\
\text { NOK}^{*}\end{array}$ & $\begin{array}{l}\text { NLG } \\
\text { ITL* }^{*} \\
\text { DKK }\end{array}$ \\
\hline $\begin{array}{l}\text { The Amsterdam summit adopts the } \\
\text { Stability and Growth Pact } \\
(97 / 17 / 06)\end{array}$ & $\begin{array}{l}\text { ATS } \\
\text { FIM } \\
\text { ITL } \\
\text { GBP* }^{*}\end{array}$ & $\begin{array}{l}\text { BEF } \\
\text { FRF } \\
\text { PTE } \\
\text { SEK }^{*}\end{array}$ & $\begin{array}{l}\text { NLG } \\
\text { IEP } \\
\text { ESP }\end{array}$ & $\begin{array}{l}\text { DEM } \\
\text { NOK}^{*}\end{array}$ & $\begin{array}{l}\text { DKK } \\
\mathrm{CHF}^{*}\end{array}$ & GRD* \\
\hline $\begin{array}{l}\text { The Brussels summit decides the member } \\
\text { states of the EMU } \\
(98 / 02 / 05)\end{array}$ & $\begin{array}{l}\text { FRF } \\
\text { NOK}^{*}\end{array}$ & $\begin{array}{l}\text { DEM } \\
\mathrm{CHF}^{*}\end{array}$ & GRD & $\begin{array}{l}\text { ATS } \\
\text { FIM } \\
\text { PTE } \\
\text { DKK }\end{array}$ & $\begin{array}{l}\text { BEF } \\
\text { IEP } \\
\text { ESP } \\
\mathrm{SEK}^{*}\end{array}$ & $\begin{array}{l}\text { NLG } \\
\text { ITL } \\
\text { GBP* }^{*}\end{array}$ \\
\hline
\end{tabular}

Note: Currencies in bold type are strongly more or less stable.

* Currency for a country that at that moment did not participate in the ERM.

** Currency that at that moment had a link to the ECU. 
Table II: The change in the stability of the currencies (utilizing the average Lyapunov exponent) at dates that are important for the EEC/EU as a whole

\begin{tabular}{|c|c|c|c|c|c|c|}
\hline \multirow{2}{*}{$\begin{array}{l}\text { Event } \\
\text { The Maastricht Treaty is agreed upon } \\
\quad(91 / 10 / 12)\end{array}$} & \multicolumn{3}{|c|}{ Weakly more stable } & \multicolumn{3}{|c|}{ Weakly less stable } \\
\hline & $\begin{array}{l}\text { ATS }^{*} \\
\text { FIM }^{* *} \\
\text { ITL } \\
\text { GBP } \\
\text { NOK }^{* *}\end{array}$ & $\begin{array}{l}\text { BEF } \\
\text { DEM } \\
\text { PTE* }^{*} \\
\text { DKK } \\
\text { CHF* }^{*}\end{array}$ & $\begin{array}{l}\text { NLG } \\
\text { IEP } \\
\text { ESP } \\
\text { GRD* }\end{array}$ & FRF & SEK $^{* *}$ & \\
\hline $\begin{array}{l}\text { The Danish public votes against the } \\
\text { Maastricht Treaty } \\
(92 / 02 / 06)\end{array}$ & $\begin{array}{l}\text { NLG } \\
\text { DKK }\end{array}$ & IEP & ESP & $\begin{array}{l}\text { ATS* } \\
\text { FRF } \\
\text { PTE } \\
\text { SEK }\end{array}$ & $\begin{array}{l}\text { BEF } \\
\text { DEM } \\
\text { GBP } \\
\text { NOK }^{* *}\end{array}$ & $\begin{array}{l}\text { FIM }^{* *} \\
\text { ITL } \\
\text { GRD }^{*} \\
\text { CHF* }^{*}\end{array}$ \\
\hline $\begin{array}{l}\text { The fluctuation bands within the ERM } \\
\text { are widened considerably } \\
(93 / 02 / 08)\end{array}$ & $\begin{array}{l}\text { ATS* }^{*} \\
\text { FIM }^{*} \\
\text { PTE } \\
\text { NOK }^{*}\end{array}$ & $\begin{array}{l}\text { BEF } \\
\text { FRF } \\
\text { GRD }^{*}\end{array}$ & $\begin{array}{l}\text { NLG } \\
\text { DEM } \\
\text { SEK }^{*}\end{array}$ & $\begin{array}{l}\text { IEP } \\
\text { GBP* }^{*}\end{array}$ & $\begin{array}{l}\text { ITL* }^{*} \\
\text { DKK }\end{array}$ & $\begin{array}{l}\mathrm{ESP} \\
\text { CHF }^{*}\end{array}$ \\
\hline $\begin{array}{l}\text { The Madrid summit adopts the } \\
\text { Commission's Green Paper } \\
(95 / 16 / 12)\end{array}$ & $\begin{array}{l}\text { FRF } \\
\text { ESP } \\
\text { NOK }^{*}\end{array}$ & $\begin{array}{l}\text { DEM } \\
\text { GBP }^{*} \\
\text { CHF }^{*}\end{array}$ & $\begin{array}{l}\text { IEP } \\
\text { GRD* }\end{array}$ & $\begin{array}{l}\text { ATS } \\
\text { FIM }^{*} \\
\text { DKK }\end{array}$ & $\begin{array}{l}\text { BEF } \\
\text { ITL* }^{*} \\
\text { SEK }^{*}\end{array}$ & $\begin{array}{l}\text { NLG } \\
\text { PTE }\end{array}$ \\
\hline $\begin{array}{l}\text { The Amsterdam summit adopts the } \\
\text { Stability and Growth Pact } \\
(97 / 17 / 06)\end{array}$ & $\begin{array}{l}\text { ATS } \\
\text { FIM } \\
\text { PTE } \\
\text { DKK }\end{array}$ & $\begin{array}{l}\text { BEF } \\
\text { FRF } \\
\text { ESP } \\
\text { SEK }^{*}\end{array}$ & $\begin{array}{l}\text { NLG } \\
\text { IEP } \\
\text { GBP }^{*}\end{array}$ & $\begin{array}{l}\text { DEM } \\
\text { NOK }^{*}\end{array}$ & $\begin{array}{l}\text { ITL } \\
\text { CHF }^{*}\end{array}$ & $\mathrm{GRD}^{*}$ \\
\hline $\begin{array}{l}\text { The Brussels summit decides the member } \\
\text { states of the EMU } \\
(98 / 02 / 05)\end{array}$ & $\begin{array}{l}\text { FRF } \\
\text { NOK }^{*}\end{array}$ & $\begin{array}{l}\text { DEM } \\
\text { CHF }^{*}\end{array}$ & GRD & $\begin{array}{l}\text { ATS } \\
\text { FIM } \\
\text { PTE } \\
\text { DKK }\end{array}$ & $\begin{array}{l}\text { BEF } \\
\text { IEP } \\
\text { ESP } \\
\text { SEK }^{*}\end{array}$ & $\begin{array}{l}\text { NLG } \\
\text { ITL } \\
\text { GBP }^{*}\end{array}$ \\
\hline $\begin{array}{l}\text { Note: Currencies in bold type are strongly more } \\
\text { Currency for a country that at that moment } \\
\text { C Currency that at that moment had a link to }\end{array}$ & $\begin{array}{l}\text { less stab } \\
\text { not parti } \\
\text { ECU. }\end{array}$ & le. & he E & & & \\
\hline
\end{tabular}


Table III: The change in the stability of the currencies (utilizing the largest Lyapunov exponent) at dates that are important for a specific country

\begin{tabular}{ll}
\hline \hline Event & Change of stability \\
\hline
\end{tabular}

The Austrian public votes for membership of the EU (94/12/06)

Austria joins the ERM (95/08/01)

Finland severs the Finnish Markka's link to the ECU (92/08/09)

The Finnish public votes for membership of the EU (94/16/10)

Finland joins the ERM (96/14/10)

The French public votes for the Maastricht Treaty (92/20/09)

Exchange control imposed in Ireland $(92 / 24 / 09)$

Ireland lifts the exchange control $(93 / 01 / 01)$

The EU's monetary committe suspends Italy from the ERM $(92 / 17 / 09)^{*}$

Italy rejoins the ERM $(96 / 24 / 11)$

Portugal joins the ERM (92/06/04)

Exchange control imposed in Portugal (92/24/09)

Portugal lifts the exchange control (93/01/01)

Exchange control imposed in Spain (92/23/09)

Spain lifts the exchange control (93/01/01)

The United Kingdom suspends the British Pound from the ERM (92/17/09)

The Danish public votes against the Maastricht Treaty (92/02/06)

The Danish public votes for a second version of the Maastricht Treaty (93/18/05)

Denmark joins the ERM2 (99/01/01)

The Danish public votes against membership of the EMU (00/28/09)

Greece joins the ERM2 (99/01/01)

Greece accepted as a member state of the EMU (00/19/06)

Sweden severs the Swedish Krona's link to the ECU (92/19/11)

The Swedish public votes for membership of the EU (94/13/10)

Norway severs the Norwegian Krone's link to the ECU (92/10/12)

The Norwegian public votes against membership of the EU (94/28/11)
Weakly more stable

Strongly more stable

Weakly more stable

Weakly less stable

Weakly more stable

Weakly more stable

Strongly less stable

Strongly more stable

Weakly more stable

Weakly more stable

Weakly more stable

Weakly more stable

Weakly less stable

Weakly less stable

Weakly more stable

Strongly more stable

Weakly less stable

Weakly more stable

Weakly less stable

Weakly more stable

Weakly less stable

Weakly less stable

Weakly more stable

Strongly less stable

Weakly more stable Weakly less stable

* The breakpoint is three days earlier $(92 / 14 / 09)$, when the Italian Lira was devaluated. 
Table IV: The change in the stability of the currencies (utilizing the average Lyapunov exponent) at dates that are important for a specific country

\begin{tabular}{ll}
\hline \hline Event & Change of stability
\end{tabular}

The Austrian public votes for membership of the EU (94/12/06)

Austria joins the ERM (95/08/01)

Finland severs the Finnish Markka's link to the ECU (92/08/09)

The Finnish public votes for membership of the EU (94/16/10)

Finland joins the ERM (96/14/10)

The French public votes for the Maastricht Treaty (92/20/09)

Exchange control imposed in Ireland $(92 / 24 / 09)$

Ireland lifts the exchange control $(93 / 01 / 01)$

The EU's monetary committe suspends Italy from the ERM $(92 / 17 / 09)^{*}$

Italy rejoins the ERM (96/24/11)

Portugal joins the ERM (92/06/04)

Exchange control imposed in Portugal (92/24/09)

Portugal lifts the exchange control $(93 / 01 / 01)$

Exchange control imposed in Spain (92/23/09)

Spain lifts the exchange control $(93 / 01 / 01)$

The United Kingdom suspends the British Pound from the ERM (92/17/09)

The Danish public votes against the Maastricht Treaty (92/02/06)

The Danish public votes for a second version of the Maastricht Treaty (93/18/05)

Denmark joins the ERM2 (99/01/01)

The Danish public votes against membership of the EMU (00/28/09)

Greece joins the ERM2 (99/01/01)

Greece accepted as a member state of the EMU (00/19/06)

Sweden severs the Swedish Krona's link to the ECU (92/19/11)

The Swedish public votes for membership of the EU (94/13/10)

Norway severs the Norwegian Krone's link to the ECU (92/10/12)

The Norwegian public votes against membership of the EU (94/28/11)
Weakly more stable

Strongly more stable

Weakly more stable

Weakly less stable

Weakly more stable

Weakly less stable

Weakly less stable

Strongly more stable

Weakly more stable

Weakly more stable

Weakly more stable

Weakly more stable

Weakly less stable

Weakly less stable

Weakly more stable

Weakly more stable

Weakly more stable

Weakly more stable

Strongly less stable

Weakly more stable

Weakly less stable

Weakly less stable

Weakly more stable Strongly less stable

Weakly more stable Weakly less stable

* The breakpoint is three days earlier $(92 / 14 / 09)$, when the Italian Lira was devaluated. 
Table V: The change in the volatility of the currencies at dates that are important for the EEC/EU as a whole

\begin{tabular}{|c|c|c|c|c|c|c|}
\hline Event & Weakl & $y$ more $v$ & volatile & Weak & dy less v & olatile \\
\hline $\begin{array}{l}\text { The Maastricht Treaty is agreed upon } \\
(91 / 10 / 12)\end{array}$ & $\begin{array}{l}\mathrm{BEF} \\
\mathrm{NOK}^{* *}\end{array}$ & IEP & GRD $^{*}$ & $\begin{array}{l}\text { ATS* } \\
\text { FRF } \\
\text { PTE* } \\
\text { DKK }\end{array}$ & $\begin{array}{l}\text { NLG } \\
\text { DEM } \\
\text { ESP } \\
\text { SEK }^{* *}\end{array}$ & $\begin{array}{l}\text { FIM }^{* *} \\
\text { ITL } \\
\text { GBP } \\
\text { CHF* }^{*}\end{array}$ \\
\hline $\begin{array}{l}\text { The Danish public votes against the } \\
\text { Maastricht Treaty } \\
(92 / 02 / 06)\end{array}$ & $\begin{array}{l}\text { ATS* }^{*} \\
\text { FIM** } \\
\text { IEP } \\
\text { ESP } \\
\text { GRD }^{*} \\
\text { CHF }^{*}\end{array}$ & $\begin{array}{l}\text { BEF } \\
\text { FRF } \\
\text { ITL } \\
\text { GBP } \\
\text { SEK }^{* *}\end{array}$ & $\begin{array}{l}\text { NLG } \\
\text { DEM } \\
\text { PTE } \\
\text { DKK } \\
\text { NOK }^{* *}\end{array}$ & & & \\
\hline $\begin{array}{l}\text { The fluctuation bands within the ERM } \\
\text { are widened considerably } \\
(93 / 02 / 08)\end{array}$ & $\begin{array}{l}\text { FRF } \\
\text { ESP } \\
\text { SEK }^{*}\end{array}$ & $\begin{array}{l}\text { IEP } \\
\text { GBP* }\end{array}$ & $\begin{array}{l}\text { ITL* }^{*} \\
\text { GRD* }\end{array}$ & $\begin{array}{l}\text { ATS* }^{*} \\
\text { FIM* } \\
\text { DKK }\end{array}$ & $\begin{array}{l}\text { BEF } \\
\text { DEM } \\
\text { NOK }^{*}\end{array}$ & $\begin{array}{l}\text { NLG } \\
\text { PTE } \\
\text { CHF }^{*}\end{array}$ \\
\hline $\begin{array}{l}\text { The Madrid summit adopts the } \\
\text { Commission's Green Paper } \\
(95 / 16 / 12)\end{array}$ & $\begin{array}{l}\text { ATS } \\
\text { FIM* }^{*} \\
\text { ITL* }^{*} \\
\text { NOK}^{*}\end{array}$ & $\begin{array}{l}\text { BEF } \\
\text { FRF } \\
\text { PTE } \\
\text { CHF }^{*}\end{array}$ & $\begin{array}{l}\text { NLG } \\
\text { DEM } \\
\text { DKK }\end{array}$ & $\begin{array}{l}\text { IEP } \\
\text { GRD* }\end{array}$ & $\begin{array}{l}\text { ESP } \\
\text { SEK }^{*}\end{array}$ & GBP $^{*}$ \\
\hline $\begin{array}{l}\text { The Amsterdam summit adopts the } \\
\text { Stability and Growth Pact } \\
(97 / 17 / 06)\end{array}$ & GRD* $^{*}$ & & & $\begin{array}{l}\text { ATS } \\
\text { FIM } \\
\text { IEP } \\
\text { ESP } \\
\text { SEK* }\end{array}$ & $\begin{array}{l}\text { BEF } \\
\text { FRF } \\
\text { ITL } \\
\text { GBP* } \\
\text { NOK}^{*}\end{array}$ & $\begin{array}{l}\text { NLG } \\
\text { DEM } \\
\text { PTE } \\
\text { DKK } \\
\text { CHF }^{*}\end{array}$ \\
\hline $\begin{array}{l}\text { The Brussels summit decides the member } \\
\text { states of the EMU } \\
(98 / 02 / 05)\end{array}$ & $\begin{array}{l}\text { ATS } \\
\text { FIM } \\
\text { ITL } \\
\text { DKK }\end{array}$ & $\begin{array}{l}\text { BEF } \\
\text { FRF } \\
\text { PTE } \\
\text { SEK }\end{array}$ & $\begin{array}{l}\text { NLG } \\
\text { DEM } \\
\text { ESP } \\
\text { NOK* }\end{array}$ & $\begin{array}{l}\text { IEP } \\
\text { CHF }^{*}\end{array}$ & GBP $^{*}$ & GRD \\
\hline
\end{tabular}


Table VI: The change in the volatility of the currencies at dates that are important for a specific country

Event
The Austrian public votes for membership of the EU $(94 / 12 / 06)$
Austria joins the ERM $(95 / 08 / 01)$

Finland severs the Finnish Markka's link to the ECU (92/08/09)

The Finnish public votes for membership of the EU (94/16/10)

Finland joins the ERM (96/14/10)

The French public votes for the Maastricht Treaty (92/20/09)

Exchange control imposed in Ireland $(92 / 24 / 09)$

Ireland lifts the exchange control $(93 / 01 / 01)$

The EU's monetary committe suspends Italy from the ERM $(92 / 17 / 09)^{*}$

Italy rejoins the ERM $(96 / 24 / 11)$

Portugal joins the ERM (92/06/04)

Exchange control imposed in Portugal (92/24/09)

Portugal lifts the exchange control (93/01/01)

Exchange control imposed in Spain $(92 / 23 / 09)$

Spain lifts the exchange control $(93 / 01 / 01)$

The United Kingdom suspends the British Pound from the ERM (92/17/09)

The Danish public votes against the Maastricht Treaty (92/02/06)

The Danish public votes for a second version of the Maastricht Treaty (93/18/05)

Denmark joins the ERM2 (99/01/01)

The Danish public votes against membership of the EMU (00/28/09)

Greece joins the ERM2 (99/01/01)

Greece accepted as a member state of the EMU (00/19/06)

Sweden severs the Swedish Krona's link to the ECU (92/19/11)

The Swedish public votes for membership of the EU (94/13/10)

Norway severs the Norwegian Krone's link to the ECU (92/10/12)

The Norwegian public votes against membership of the EU (94/28/11)
Change of volatility

Weakly less volatile Strongly more volatile

Weakly less volatile Weakly less volatile Weakly less volatile

Strongly less volatile

Weakly more volatile Strongly more volatile

Strongly more volatile Weakly less volatile

Strongly less volatile Weakly less volatile Weakly more volatile

Strongly less volatile Weakly more volatile

Weakly less volatile

Strongly more volatile Weakly more volatile Weakly less volatile Weakly less volatile

Weakly less volatile Strongly more volatile

Weakly more volatile Weakly more volatile

Weakly more volatile Strongly more volatile

* The breakpoint is three days earlier $(92 / 14 / 09)$, when the Italian Lira was devaluated. 
Table VII: The change in the volatility of the exogenous shocks to the currencies at dates that are important for the EEC/EU as a whole

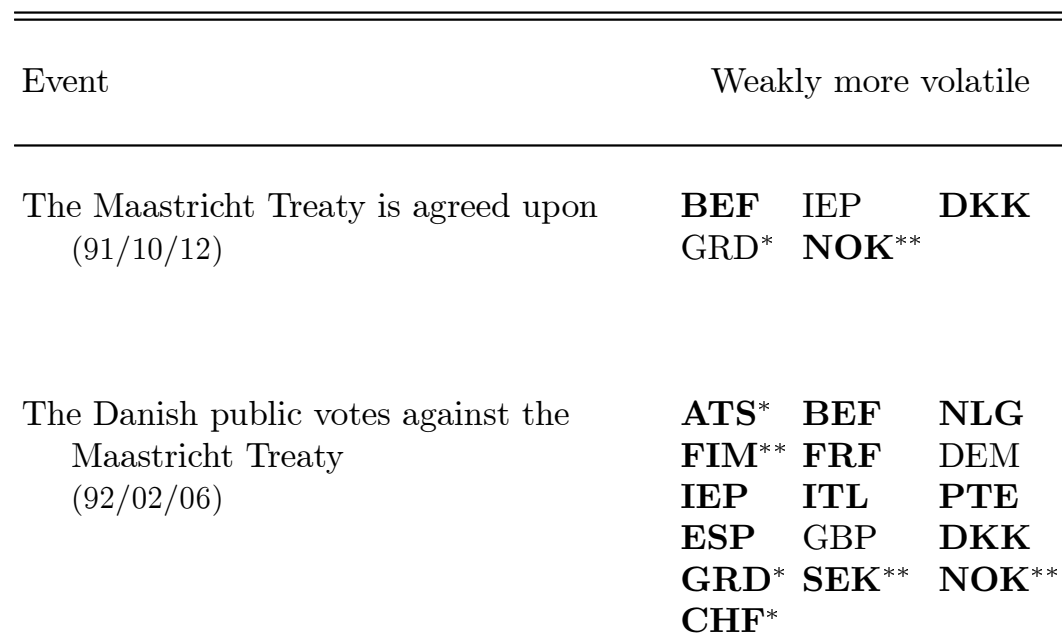

The fluctuation bands within the ERM are widened considerably $(93 / 02 / 08)$

The Madrid summit adopts the Commission's Green Paper $(95 / 16 / 12)$

The Amsterdam summit adopts the Stability and Growth Pact $(97 / 17 / 06)$

The Brussels summit decides the member states of the EMU (98/02/05)

\begin{tabular}{|c|c|c|c|c|c|}
\hline FRF & DEM & IEP & ATS $^{*}$ & BEF & NLG \\
\hline ITL* & $\mathrm{GBP}^{*}$ & GRD* & FIM ${ }^{*}$ & PTE & ESP \\
\hline SEK $^{*}$ & & & DKK & NOK $^{*}$ & CHF $^{*}$ \\
\hline ATS & BEF & NLG & IEP & ESP & GRD* \\
\hline FIM $^{*}$ & FRF & DEM & SEK ${ }^{*}$ & & \\
\hline ITL* & PTE & $\mathrm{GBP}^{*}$ & & & \\
\hline DKK & $\mathrm{NOK}^{*}$ & $\mathrm{CHF}^{*}$ & & & \\
\hline \multirow[t]{5}{*}{ GRD* } & & & ATS & $\mathrm{BEF}$ & NLG \\
\hline & & & FIM & FRF & DEM \\
\hline & & & IEP & ITL & PTE \\
\hline & & & ESP & $\mathrm{GBP}^{*}$ & DKK \\
\hline & & & SEK $^{*}$ & $\mathrm{NOK}^{*}$ & $\mathrm{CHF}^{*}$ \\
\hline ATS & $\mathrm{BEF}$ & NLG & IEP & ITL & GBP $^{*}$ \\
\hline FIM & FRF & DEM & GRD & $\mathrm{CHF}^{*}$ & \\
\hline PTE & ESP & DKK & & & \\
\hline SEK ${ }^{*}$ & NOK & & & & \\
\hline
\end{tabular}

ATS $^{*}$ NLG FIM $^{* *}$

FRF DEM ITL

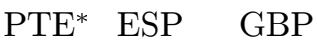
$\mathrm{SEK}^{* *} \mathrm{CHF}^{*}$

Weakly less volatile 
Table VIII: The change in the volatility of the exogenous shocks to the currencies at dates that are important for a specific country

\begin{tabular}{ll}
\hline \hline Event & Change of volatility
\end{tabular}

The Austrian public votes for membership of the EU (94/12/06)

Austria joins the ERM (95/08/01)

Finland severs the Finnish Markka's link to the ECU (92/08/09)

The Finnish public votes for membership of the EU (94/16/10)

Finland joins the ERM (96/14/10)

The French public votes for the Maastricht Treaty (92/20/09)

Exchange control imposed in Ireland $(92 / 24 / 09)$

Ireland lifts the exchange control $(93 / 01 / 01)$

The EU's monetary committe suspends Italy from the ERM $(92 / 17 / 09)^{*}$

Italy rejoins the ERM $(96 / 24 / 11)$

Portugal joins the ERM (92/06/04)

Exchange control imposed in Portugal (92/24/09)

Portugal lifts the exchange control (93/01/01)

Exchange control imposed in Spain (92/23/09)

Spain lifts the exchange control $(93 / 01 / 01)$

The United Kingdom suspends the British Pound from the ERM (92/17/09)

The Danish public votes against the Maastricht Treaty (92/02/06)

The Danish public votes for a second version of the Maastricht Treaty (93/18/05)

Denmark joins the ERM2 (99/01/01)

The Danish public votes against membership of the EMU (00/28/09)

Greece joins the ERM2 (99/01/01)

Greece accepted as a member state of the EMU (00/19/06)

Sweden severs the Swedish Krona's link to the ECU (92/19/11)

The Swedish public votes for membership of the EU (94/13/10)

Norway severs the Norwegian Krone's link to the ECU (92/10/12)

The Norwegian public votes against membership of the EU (94/28/11)
Weakly less volatile Strongly more volatile

Weakly less volatile Weakly less volatile Weakly less volatile

Weakly more volatile

Weakly more volatile Strongly more volatile

Strongly more volatile Weakly less volatile

Strongly less volatile Strongly less volatile Weakly more volatile

Strongly less volatile Weakly more volatile

Strongly more volatile

Strongly more volatile Weakly more volatile Weakly less volatile Weakly less volatile

Weakly less volatile Weakly less volatile

Weakly more volatile Weakly more volatile

Weakly more volatile Strongly more volatile

* The breakpoint is three days earlier $(92 / 14 / 09)$, when the Italian Lira was devaluated. 
Table IX: The Austrian Schilling against the ECU

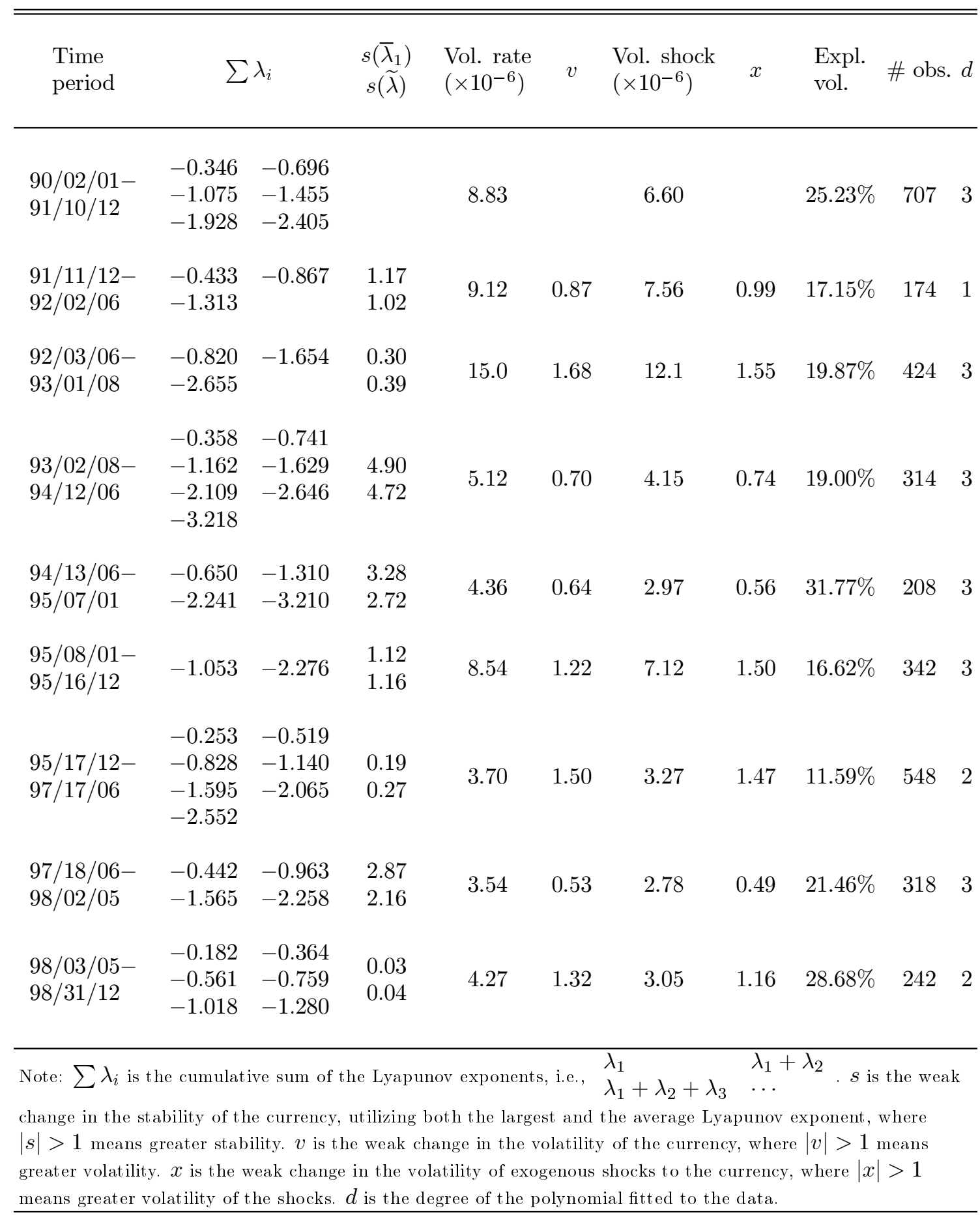


Table X: The Austrian Schilling against the U.S. Dollar

\begin{tabular}{|c|c|c|c|c|c|c|c|}
\hline $\begin{array}{l}\text { Time } \\
\text { period }\end{array}$ & \multicolumn{2}{|c|}{$\sum \lambda_{i}$} & $\begin{array}{l}\text { Vol. rate } \\
\left(\times 10^{-6}\right)\end{array}$ & $\begin{array}{l}\text { Vol. shock } \\
\left(\times 10^{-6}\right)\end{array}$ & $\begin{array}{l}\text { Expl. } \\
\text { vol. }\end{array}$ & \# obs. & $d$ \\
\hline $\begin{array}{l}90 / 02 / 01- \\
91 / 10 / 12\end{array}$ & $\begin{array}{l}-0.615 \\
-2.053 \\
-3.754\end{array}$ & $\begin{array}{l}-1.273 \\
-2.883\end{array}$ & 36.1 & 35.2 & $2.58 \%$ & 707 & 3 \\
\hline $\begin{array}{l}91 / 11 / 12- \\
92 / 02 / 06\end{array}$ & $\begin{array}{l}-0.660 \\
-2.408\end{array}$ & -1.420 & 42.8 & 40.8 & $4.69 \%$ & 174 & 2 \\
\hline $\begin{array}{l}92 / 03 / 06- \\
93 / 01 / 08\end{array}$ & \multicolumn{2}{|c|}{-4.156} & 42.0 & 42.0 & $0.02 \%$ & 424 & $1^{*}$ \\
\hline $\begin{array}{l}93 / 02 / 08- \\
94 / 12 / 06\end{array}$ & $\begin{array}{l}-0.370 \\
-1.232 \\
-2.287\end{array}$ & $\begin{array}{l}-0.778 \\
-1.722\end{array}$ & 20.5 & 19.5 & $4.46 \%$ & 314 & 3 \\
\hline $\begin{array}{l}94 / 13 / 06- \\
95 / 07 / 01\end{array}$ & $\begin{array}{l}-0.205 \\
-0.694 \\
-1.333 \\
-2.054\end{array}$ & $\begin{array}{l}-0.431 \\
-1.012 \\
-1.672\end{array}$ & 27.2 & 24.9 & $8.50 \%$ & 208 & $2^{*}$ \\
\hline $\begin{array}{l}95 / 08 / 01- \\
95 / 16 / 12\end{array}$ & $\begin{array}{l}-0.297 \\
-0.963 \\
-1.697\end{array}$ & $\begin{array}{l}-0.619 \\
-1.311 \\
-2.148\end{array}$ & 43.7 & 39.8 & $8.87 \%$ & 342 & 3 \\
\hline $\begin{array}{l}95 / 17 / 12- \\
97 / 17 / 06\end{array}$ & $\begin{array}{l}-0.378 \\
-1.201 \\
-2.131\end{array}$ & $\begin{array}{l}-0.757 \\
-1.646\end{array}$ & 12.6 & 12.4 & $1.97 \%$ & 548 & 1 \\
\hline $\begin{array}{l}97 / 18 / 06- \\
98 / 02 / 05\end{array}$ & $\begin{array}{l}-0.230 \\
-0.745 \\
-1.381 \\
-2.137\end{array}$ & $\begin{array}{l}-0.466 \\
-1.039 \\
-1.744\end{array}$ & 22.9 & 21.4 & $6.44 \%$ & 318 & 2 \\
\hline $\begin{array}{l}98 / 03 / 05- \\
98 / 31 / 12\end{array}$ & -2 . & 34 & 20.9 & 20.3 & $2.65 \%$ & 242 & 2 \\
\hline $\begin{array}{l}99 / 01 / 01- \\
01 / 31 / 03\end{array}$ & -3 . & & 34.6 & 34.3 & $0.80 \%$ & 820 & 2 \\
\hline $\begin{array}{l}\text { Note: See Tabl } \\
{ }^{*} \text { The model se } \\
\text { model is a mod }\end{array}$ & $\begin{array}{l}\mathrm{X} . \\
\text { ted is the } \\
\text { vithout }\end{array}$ & $\begin{array}{l}\text { econd bes } \\
\text { lamics. }\end{array}$ & cording $t$ & IC, and is ch & n since & the best & \\
\hline
\end{tabular}


Table XI: The Belgian Franc against the ECU

\begin{tabular}{|c|c|c|c|c|c|c|c|c|c|c|}
\hline $\begin{array}{l}\text { Time } \\
\text { period }\end{array}$ & \multicolumn{2}{|c|}{$\sum \lambda_{i}$} & $\begin{array}{l}s\left(\bar{\lambda}_{1}\right) \\
s(\widetilde{\lambda})\end{array}$ & $\begin{array}{l}\text { Vol. rate } \\
\left(\times 10^{-6}\right)\end{array}$ & $v$ & $\begin{array}{l}\text { Vol. shock } \\
\left(\times 10^{-6}\right)\end{array}$ & $x$ & $\begin{array}{l}\text { Expl. } \\
\text { vol. }\end{array}$ & \# obs. & $d$ \\
\hline $\begin{array}{l}90 / 02 / 01- \\
91 / 10 / 12\end{array}$ & $\begin{array}{l}-0.276 \\
-0.947 \\
-1.793 \\
-2.980\end{array}$ & $\begin{array}{l}-0.550 \\
-1.349 \\
-2.241\end{array}$ & & 6.92 & & 4.98 & & $28.00 \%$ & 707 & 3 \\
\hline $\begin{array}{l}91 / 11 / 12- \\
92 / 02 / 06\end{array}$ & $\begin{array}{l}-0.298 \\
-1.104 \\
-2.149\end{array}$ & $\begin{array}{l}-0.598 \\
-1.622 \\
-2.693\end{array}$ & $\begin{array}{l}3.91 \\
2.37\end{array}$ & 9.39 & 1.11 & 7.06 & 1.29 & $24.83 \%$ & 174 & 3 \\
\hline $\begin{array}{l}92 / 03 / 06- \\
93 / 01 / 08\end{array}$ & -0.935 & -1.891 & $\begin{array}{l}0.19 \\
0.23\end{array}$ & 10.4 & 1.09 & 8.33 & 1.03 & $20.17 \%$ & 424 & 3 \\
\hline $\begin{array}{l}93 / 02 / 08- \\
95 / 16 / 12\end{array}$ & $\begin{array}{l}-0.485 \\
-1.556 \\
-2.729 \\
-3.995\end{array}$ & $\begin{array}{l}-1.016 \\
-2.131 \\
-3.347\end{array}$ & $\begin{array}{l}6.28 \\
6.37\end{array}$ & 5.00 & 0.73 & 4.45 & 0.84 & $11.11 \%$ & 866 & 3 \\
\hline $\begin{array}{l}95 / 17 / 12- \\
97 / 17 / 06\end{array}$ & $\begin{array}{l}-0.395 \\
-1.294 \\
-2.312\end{array}$ & $\begin{array}{l}-0.805 \\
-1.784\end{array}$ & $\begin{array}{l}0.54 \\
0.49\end{array}$ & 3.63 & 1.64 & 3.29 & 1.69 & $9.18 \%$ & 548 & 3 \\
\hline $\begin{array}{l}97 / 18 / 06- \\
98 / 02 / 05\end{array}$ & -1.046 & -2.262 & $\begin{array}{l}5.38 \\
5.01\end{array}$ & 1.47 & 0.24 & 1.33 & 0.24 & $9.63 \%$ & 318 & 2 \\
\hline $\begin{array}{l}98 / 03 / 05- \\
98 / 31 / 12\end{array}$ & $\begin{array}{l}-0.225 \\
-0.834 \\
-1.632\end{array}$ & $\begin{array}{l}-0.449 \\
-1.233\end{array}$ & $\begin{array}{l}0.11 \\
0.14\end{array}$ & 3.79 & 2.79 & 2.74 & 2.26 & $27.53 \%$ & 242 & 3 \\
\hline
\end{tabular}


Table XII: The Belgian Franc against the U.S. Dollar

\begin{tabular}{|c|c|c|c|c|c|c|c|}
\hline $\begin{array}{l}\text { Time } \\
\text { period }\end{array}$ & \multicolumn{2}{|c|}{$\sum \lambda_{i}$} & $\begin{array}{l}\text { Vol. rate } \\
\left(\times 10^{-6}\right)\end{array}$ & $\begin{array}{l}\text { Vol. shock } \\
\left(\times 10^{-6}\right)\end{array}$ & $\begin{array}{l}\text { Expl. } \\
\text { vol. }\end{array}$ & \# obs. & $d$ \\
\hline $\begin{array}{l}90 / 02 / 01- \\
91 / 10 / 12\end{array}$ & $\begin{array}{l}-0.930 \\
-3.053\end{array}$ & -1.903 & 34.7 & 34.0 & $2.04 \%$ & 707 & 3 \\
\hline $\begin{array}{l}91 / 11 / 12- \\
92 / 02 / 06\end{array}$ & $\begin{array}{l}-0.257 \\
-0.842 \\
-1.586 \\
-3.174\end{array}$ & $\begin{array}{l}-0.534 \\
-1.185 \\
-2.030\end{array}$ & 42.5 & 37.5 & $11.74 \%$ & 174 & 3 \\
\hline $\begin{array}{l}92 / 03 / 06- \\
93 / 01 / 08\end{array}$ & \multicolumn{2}{|c|}{-4.143} & 43.0 & 43.0 & $0.03 \%$ & 424 & $1^{*}$ \\
\hline $\begin{array}{l}93 / 02 / 08- \\
95 / 16 / 12\end{array}$ & $\begin{array}{l}-0.342 \\
-1.068 \\
-1.905\end{array}$ & $\begin{array}{l}-0.696 \\
-1.477 \\
-2.356\end{array}$ & 28.3 & 27.4 & $3.18 \%$ & 866 & 3 \\
\hline $\begin{array}{l}95 / 17 / 12- \\
97 / 17 / 06\end{array}$ & $\begin{array}{l}-0.520 \\
-1.757 \\
-3.253\end{array}$ & $\begin{array}{l}-1.106 \\
-2.476\end{array}$ & 12.5 & 12.0 & $4.17 \%$ & 548 & 3 \\
\hline $\begin{array}{l}97 / 18 / 06- \\
98 / 02 / 05\end{array}$ & $\begin{array}{l}-0.256 \\
-0.828 \\
-1.526\end{array}$ & $\begin{array}{l}-0.512 \\
-1.144 \\
-1.907\end{array}$ & 20.8 & 20.0 & $4.07 \%$ & 318 & 1 \\
\hline $\begin{array}{l}98 / 03 / 05- \\
98 / 31 / 12\end{array}$ & $\begin{array}{l}-0.509 \\
-1.772\end{array}$ & $\begin{array}{l}-1.125 \\
-2.608\end{array}$ & 19.2 & 18.2 & $5.52 \%$ & 242 & 3 \\
\hline $\begin{array}{l}99 / 01 / 01- \\
01 / 31 / 03\end{array}$ & $\begin{array}{l}-0.352 \\
-1.130 \\
-2.037 \\
-3.132\end{array}$ & $\begin{array}{l}-0.724 \\
-1.567 \\
-2.550\end{array}$ & 34.6 & 33.6 & $2.81 \%$ & 820 & 2 \\
\hline $\begin{array}{l}\text { ote: See Tabl } \\
\text { See note in } 1\end{array}$ & e X. & & & & & & \\
\hline
\end{tabular}


Table XIII: The Dutch Guilder against the ECU

\begin{tabular}{|c|c|c|c|c|c|c|c|c|c|c|}
\hline $\begin{array}{l}\text { Time } \\
\text { period }\end{array}$ & \multicolumn{2}{|c|}{$\sum \lambda_{i}$} & $\begin{array}{l}s\left(\bar{\lambda}_{1}\right) \\
s(\widetilde{\lambda})\end{array}$ & $\begin{array}{l}\text { Vol. rate } \\
\left(\times 10^{-6}\right)\end{array}$ & $v$ & $\begin{array}{l}\text { Vol. shock } \\
\left(\times 10^{-6}\right)\end{array}$ & $x$ & $\begin{array}{l}\text { Expl. } \\
\text { vol. }\end{array}$ & \# obs. & . $d$ \\
\hline $\begin{array}{l}90 / 02 / 01- \\
91 / 10 / 12\end{array}$ & $\begin{array}{l}-0.346 \\
-1.133 \\
-2.058 \\
-3.120\end{array}$ & $\begin{array}{l}-0.694 \\
-1.575 \\
-2.546\end{array}$ & & 5.64 & & 4.13 & & $26.65 \%$ & 707 & 3 \\
\hline $\begin{array}{l}91 / 11 / 12- \\
92 / 02 / 06\end{array}$ & $\begin{array}{l}-0.355 \\
-1.377 \\
-2.714 \\
-4.273\end{array}$ & $\begin{array}{l}-0.841 \\
-2.026 \\
-3.469\end{array}$ & $\begin{array}{l}3.33 \\
2.50\end{array}$ & 6.00 & 0.87 & 4.20 & 0.94 & $29.97 \%$ & 174 & 3 \\
\hline $\begin{array}{l}92 / 03 / 06- \\
93 / 01 / 08\end{array}$ & $\begin{array}{l}-0.590 \\
-2.004\end{array}$ & -1.216 & $\begin{array}{l}1.65 \\
1.83\end{array}$ & 11.2 & 1.99 & 9.33 & 2.19 & $16.44 \%$ & 424 & 3 \\
\hline $\begin{array}{l}93 / 02 / 08- \\
95 / 16 / 12\end{array}$ & $\begin{array}{l}-1.095 \\
-3.668\end{array}$ & -2.319 & $\begin{array}{l}0.90 \\
1.04\end{array}$ & 3.90 & 0.48 & 3.74 & 0.52 & $4.04 \%$ & 866 & 3 \\
\hline $\begin{array}{l}95 / 17 / 12- \\
97 / 17 / 06\end{array}$ & $\begin{array}{l}-0.604 \\
-2.001 \\
-3.760\end{array}$ & $\begin{array}{l}-1.278 \\
-2.839\end{array}$ & $\begin{array}{l}0.34 \\
0.36\end{array}$ & 2.61 & 1.53 & 2.36 & 1.49 & $9.32 \%$ & 548 & 3 \\
\hline $\begin{array}{l}97 / 18 / 06- \\
98 / 02 / 05\end{array}$ & $\begin{array}{l}-0.381 \\
-1.261 \\
-2.237\end{array}$ & $\begin{array}{l}-0.814 \\
-1.739 \\
-2.761\end{array}$ & $\begin{array}{l}2.68 \\
2.06\end{array}$ & 1.41 & 0.32 & 1.25 & 0.34 & $10.87 \%$ & 318 & 3 \\
\hline $\begin{array}{l}98 / 03 / 05- \\
98 / 31 / 12\end{array}$ & $\begin{array}{l}-0.270 \\
-1.016 \\
-2.174\end{array}$ & $\begin{array}{l}-0.563 \\
-1.475 \\
-2.887\end{array}$ & $\begin{array}{l}0.28 \\
0.45\end{array}$ & 2.94 & 2.19 & 2.20 & 1.70 & $25.17 \%$ & 242 & 3 \\
\hline te: See Tal & & & & & & & & & & \\
\hline
\end{tabular}


Table XIV: The Dutch Guilder against the U.S. Dollar

\begin{tabular}{|c|c|c|c|c|c|c|c|}
\hline $\begin{array}{l}\text { Time } \\
\text { period }\end{array}$ & \multicolumn{2}{|c|}{$\sum \lambda_{i}$} & $\begin{array}{l}\text { Vol. rate } \\
\left(\times 10^{-6}\right)\end{array}$ & $\begin{array}{l}\text { Vol. shock } \\
\left(\times 10^{-6}\right)\end{array}$ & $\begin{array}{l}\text { Expl. } \\
\text { vol. }\end{array}$ & \multicolumn{2}{|c|}{ \# obs. $d$} \\
\hline $\begin{array}{l}90 / 02 / 01- \\
91 / 10 / 12\end{array}$ & $\begin{array}{l}-0.783 \\
-2.630\end{array}$ & $\begin{array}{l}-1.655 \\
-3.722\end{array}$ & 33.9 & 33.0 & $2.84 \%$ & 707 & 3 \\
\hline $\begin{array}{l}91 / 11 / 12- \\
92 / 02 / 06\end{array}$ & $\begin{array}{l}-0.241 \\
-0.775 \\
-1.562 \\
-3.566\end{array}$ & $\begin{array}{l}-0.474 \\
-1.137 \\
-2.045\end{array}$ & 41.4 & 35.8 & $13.45 \%$ & 174 & 3 \\
\hline $\begin{array}{l}92 / 03 / 06- \\
93 / 01 / 08\end{array}$ & $\begin{array}{l}-0.243 \\
-0.763 \\
-1.360 \\
-2.130\end{array}$ & $\begin{array}{l}-0.496 \\
-1.056 \\
-1.698\end{array}$ & 38.9 & 36.3 & $6.82 \%$ & 424 & 3 \\
\hline $\begin{array}{l}93 / 02 / 08- \\
95 / 16 / 12\end{array}$ & $\begin{array}{l}-0.501 \\
-1.543 \\
-2.680\end{array}$ & $\begin{array}{l}-1.014 \\
-2.106\end{array}$ & 28.3 & 28.1 & $0.69 \%$ & 866 & 3 \\
\hline $\begin{array}{l}95 / 17 / 12- \\
97 / 17 / 06\end{array}$ & $\begin{array}{l}-0.802 \\
-2.744\end{array}$ & -1.703 & 12.4 & 11.9 & $3.60 \%$ & 548 & 3 \\
\hline $\begin{array}{l}97 / 18 / 06- \\
98 / 02 / 05\end{array}$ & $\begin{array}{l}-0.189 \\
-0.667 \\
-1.232 \\
-1.903\end{array}$ & $\begin{array}{l}-0.418 \\
-0.938 \\
-1.553\end{array}$ & 21.0 & 18.8 & $10.35 \%$ & 318 & 3 \\
\hline $\begin{array}{l}98 / 03 / 05- \\
98 / 31 / 12\end{array}$ & $\begin{array}{l}-0.485 \\
-1.676\end{array}$ & $\begin{array}{l}-1.023 \\
-2.513\end{array}$ & 20.0 & 19.5 & $2.83 \%$ & 242 & 3 \\
\hline $\begin{array}{l}99 / 01 / 01- \\
01 / 31 / 03\end{array}$ & -3 . & 456 & 34.6 & 34.3 & $0.80 \%$ & 820 & 2 \\
\hline
\end{tabular}


Table XV: The Finnish Markka against the ECU

\begin{tabular}{|c|c|c|c|c|c|c|c|c|c|c|}
\hline $\begin{array}{l}\text { Time } \\
\text { period }\end{array}$ & \multicolumn{2}{|c|}{$\sum \lambda_{i}$} & $\begin{array}{l}s\left(\bar{\lambda}_{1}\right) \\
s(\widetilde{\lambda})\end{array}$ & $\begin{array}{l}\text { Vol. rate } \\
\left(\times 10^{-6}\right)\end{array}$ & $v$ & $\begin{array}{l}\text { Vol. shock } \\
\left(\times 10^{-6}\right)\end{array}$ & $x$ & $\begin{array}{l}\text { Expl. } \\
\text { vol. }\end{array}$ & \multicolumn{2}{|c|}{ \# obs. } \\
\hline $\begin{array}{l}90 / 02 / 01- \\
91 / 10 / 12\end{array}$ & $\begin{array}{l}-0.488 \\
-1.559\end{array}$ & $\begin{array}{l}-0.978 \\
-2.715\end{array}$ & & 22.5 & & 21.8 & & $3.15 \%$ & 707 & 2 \\
\hline $\begin{array}{l}91 / 11 / 12- \\
92 / 02 / 06\end{array}$ & $\begin{array}{l}-0.891 \\
-3.304\end{array}$ & -2.042 & $\begin{array}{l}12.4 \\
4.94\end{array}$ & 10.3 & 0.50 & 8.24 & 0.45 & $20.29 \%$ & 174 & 3 \\
\hline $\begin{array}{l}92 / 03 / 06- \\
92 / 08 / 09\end{array}$ & $\begin{array}{l}-0.221 \\
-0.886\end{array}$ & -0.482 & $\begin{array}{l}0.06 \\
0.15\end{array}$ & 44.0 & 2.94 & 26.4 & 2.41 & $39.87 \%$ & 97 & 2 \\
\hline $\begin{array}{l}92 / 09 / 09- \\
93 / 01 / 08\end{array}$ & $\begin{array}{l}-0.377 \\
-1.291 \\
-2.336\end{array}$ & $\begin{array}{l}-0.805 \\
-1.790\end{array}$ & $\begin{array}{l}2.72 \\
1.86\end{array}$ & 28.7 & 0.65 & 23.7 & 0.77 & $17.57 \%$ & 326 & 3 \\
\hline $\begin{array}{l}93 / 02 / 08- \\
94 / 16 / 10\end{array}$ & $\begin{array}{l}-0.522 \\
-1.751\end{array}$ & $\begin{array}{l}-1.802 \\
-2.525\end{array}$ & $\begin{array}{l}2.31 \\
2.55\end{array}$ & 10.3 & 0.91 & 9.27 & 0.96 & $9.93 \%$ & 440 & 3 \\
\hline $\begin{array}{l}94 / 17 / 10- \\
95 / 16 / 12\end{array}$ & $\begin{array}{l}-0.503 \\
-1.789 \\
-3.441\end{array}$ & $\begin{array}{l}-1.099 \\
-2.573\end{array}$ & $\begin{array}{l}0.62 \\
0.81\end{array}$ & 9.20 & 0.81 & 8.39 & 0.82 & $8.85 \%$ & 425 & 3 \\
\hline $\begin{array}{l}95 / 17 / 12- \\
96 / 13 / 10\end{array}$ & $\begin{array}{l}-0.271 \\
-0.956 \\
-1.723 \\
-2.592\end{array}$ & $\begin{array}{l}-0.597 \\
-1.313 \\
-2.158\end{array}$ & $\begin{array}{l}0.06 \\
0.07\end{array}$ & 6.78 & 1.69 & 6.37 & 1.73 & $6.00 \%$ & 301 & 3 \\
\hline $\begin{array}{l}96 / 14 / 10- \\
97 / 17 / 06\end{array}$ & $\begin{array}{l}-0.287 \\
-0.932 \\
-1.851 \\
-3.036\end{array}$ & $\begin{array}{l}-0.564 \\
-1.334 \\
-2.424\end{array}$ & $\begin{array}{l}11.0 \\
4.07\end{array}$ & 7.78 & 0.84 & 6.58 & 0.80 & $15.40 \%$ & 246 & 3 \\
\hline $\begin{array}{l}97 / 18 / 06- \\
98 / 02 / 05\end{array}$ & $\begin{array}{l}-0.217 \\
-0.743 \\
-1.446 \\
-2.314\end{array}$ & $\begin{array}{l}-0.466 \\
-1.061 \\
-1.860\end{array}$ & $\begin{array}{l}1.09 \\
1.86\end{array}$ & 1.69 & 0.17 & 1.53 & 0.18 & $9.29 \%$ & 318 & 2 \\
\hline $\begin{array}{l}98 / 03 / 05- \\
98 / 31 / 12\end{array}$ & $\begin{array}{l}-0.574 \\
-1.723\end{array}$ & -1.147 & $\begin{array}{l}0.40 \\
0.41\end{array}$ & 2.57 & 1.66 & 2.11 & 1.46 & $17.84 \%$ & 242 & 1 \\
\hline
\end{tabular}


Table XVI: The Finnish Markka against the U.S. Dollar

\begin{tabular}{|c|c|c|c|c|c|c|c|}
\hline $\begin{array}{l}\text { Time } \\
\text { period }\end{array}$ & \multicolumn{2}{|c|}{$\sum \lambda_{i}$} & $\begin{array}{l}\text { Vol. rate } \\
\left(\times 10^{-6}\right)\end{array}$ & $\begin{array}{l}\text { Vol. shock } \\
\left(\times 10^{-6}\right)\end{array}$ & $\begin{array}{l}\text { Expl. } \\
\text { vol. }\end{array}$ & \multicolumn{2}{|c|}{ \# obs. d } \\
\hline $\begin{array}{l}90 / 02 / 01- \\
91 / 10 / 12\end{array}$ & $\begin{array}{l}-0.911 \\
-3.126\end{array}$ & $\begin{array}{l}-1.942 \\
-4.461\end{array}$ & 44.8 & 43.1 & $3.69 \%$ & 707 & 3 \\
\hline $\begin{array}{l}91 / 11 / 12- \\
92 / 02 / 06\end{array}$ & $\begin{array}{l}-0.134 \\
-0.512 \\
-0.987 \\
-2.562\end{array}$ & $\begin{array}{l}-0.297 \\
-0.743 \\
-1.298\end{array}$ & 41.1 & 36.1 & $12.17 \%$ & 174 & 3 \\
\hline $\begin{array}{l}92 / 03 / 06- \\
92 / 08 / 09\end{array}$ & $\begin{array}{l}-0.573 \\
-1.955\end{array}$ & -1.211 & 59.7 & 48.0 & $19.53 \%$ & 97 & 2 \\
\hline $\begin{array}{l}92 / 09 / 09- \\
93 / 01 / 08\end{array}$ & $\begin{array}{l}-0.359 \\
-1.152 \\
-2.253\end{array}$ & $\begin{array}{l}-0.723 \\
-1.650 \\
-3.322\end{array}$ & 60.2 & 55.7 & $7.53 \%$ & 326 & 3 \\
\hline $\begin{array}{l}93 / 02 / 08- \\
94 / 16 / 10\end{array}$ & $\begin{array}{l}-0.215 \\
-0.717 \\
-1.330 \\
-2.053\end{array}$ & $\begin{array}{l}-0.458 \\
-1.016 \\
-1.691\end{array}$ & 23.8 & 22.6 & $4.99 \%$ & 440 & 3 \\
\hline $\begin{array}{l}94 / 17 / 10- \\
95 / 16 / 12\end{array}$ & $\begin{array}{l}-0.332 \\
-1.022 \\
-1.877\end{array}$ & $\begin{array}{l}-0.667 \\
-1.437 \\
-2.362\end{array}$ & 26.2 & 24.9 & $5.15 \%$ & 425 & 2 \\
\hline $\begin{array}{l}95 / 17 / 12- \\
96 / 13 / 10\end{array}$ & -3 . & 03 & 11.4 & 10.9 & $4.12 \%$ & 301 & 3 \\
\hline $\begin{array}{l}96 / 14 / 10- \\
97 / 17 / 06\end{array}$ & $\begin{array}{l}-0.300 \\
-1.061 \\
-2.138\end{array}$ & $\begin{array}{l}-0.658 \\
-1.565 \\
-5.364\end{array}$ & 15.6 & 14.1 & $9.81 \%$ & 246 & 3 \\
\hline $\begin{array}{l}97 / 18 / 06- \\
98 / 02 / 05\end{array}$ & $\begin{array}{l}-0.208 \\
-0.746 \\
-1.434 \\
-2.562\end{array}$ & $\begin{array}{l}-0.444 \\
-1.067 \\
-1.923\end{array}$ & 19.9 & 18.5 & $6.62 \%$ & 318 & 3 \\
\hline $\begin{array}{l}98 / 03 / 05- \\
98 / 31 / 12\end{array}$ & -1.387 & -3.088 & 18.2 & 17.5 & $4.05 \%$ & 242 & 2 \\
\hline $\begin{array}{l}99 / 01 / 01- \\
01 / 31 / 03\end{array}$ & $\begin{array}{l}-0.352 \\
-1.130 \\
-2.036 \\
-3.135\end{array}$ & $\begin{array}{l}-0.723 \\
-1.567 \\
-2.548\end{array}$ & 34.6 & 33.6 & $2.81 \%$ & 820 & 2 \\
\hline
\end{tabular}


Table XVII: The French Franc against the ECU

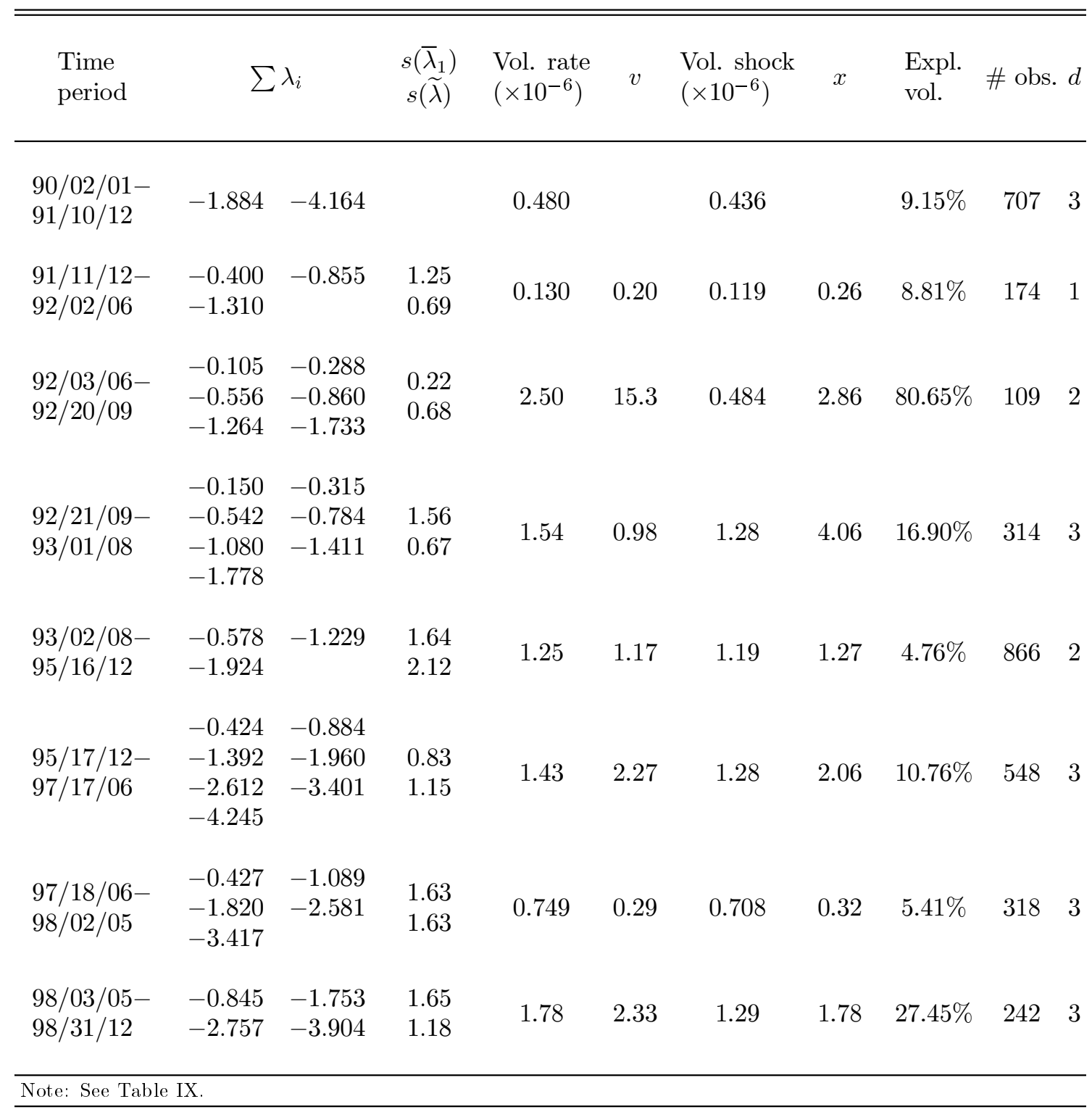


Table XVIII: The French Franc against the U.S. Dollar

\begin{tabular}{|c|c|c|c|c|c|c|c|}
\hline $\begin{array}{l}\text { Time } \\
\text { period }\end{array}$ & \multicolumn{2}{|c|}{$\sum \lambda_{i}$} & $\begin{array}{l}\text { Vol. rate } \\
\left(\times 10^{-6}\right)\end{array}$ & $\begin{array}{l}\text { Vol. shock } \\
\left(\times 10^{-6}\right)\end{array}$ & $\begin{array}{l}\text { Expl. } \\
\text { vol. }\end{array}$ & \# obs. & $d$ \\
\hline $\begin{array}{l}90 / 02 / 01- \\
91 / 10 / 12\end{array}$ & $\begin{array}{l}-0.963 \\
-3.241\end{array}$ & -2.038 & 30.2 & 29.4 & $2.83 \%$ & 707 & 3 \\
\hline $\begin{array}{l}91 / 11 / 12- \\
92 / 02 / 06\end{array}$ & $\begin{array}{l}-0.163 \\
-0.748 \\
-1.635\end{array}$ & $\begin{array}{l}-0.411 \\
-1.170\end{array}$ & 40.1 & 30.4 & $24.38 \%$ & 174 & 3 \\
\hline $\begin{array}{l}92 / 03 / 06- \\
92 / 20 / 09\end{array}$ & $\begin{array}{l}-0.196 \\
-0.708 \\
-1.584\end{array}$ & $\begin{array}{l}-0.424 \\
-1.080\end{array}$ & 50.3 & 43.3 & $13.90 \%$ & 109 & 3 \\
\hline $\begin{array}{l}92 / 21 / 09- \\
93 / 01 / 08\end{array}$ & $\begin{array}{l}-0.180 \\
-0.697 \\
-1.397 \\
-2.920\end{array}$ & $\begin{array}{l}-0.431 \\
-1.010 \\
-2.142\end{array}$ & 31.7 & 28.2 & $10.86 \%$ & 314 & 3 \\
\hline $\begin{array}{l}93 / 02 / 08- \\
95 / 16 / 12\end{array}$ & $\begin{array}{l}-0.422 \\
-1.333 \\
-2.335 \\
-3.485\end{array}$ & $\begin{array}{l}-0.869 \\
-1.826 \\
-2.885\end{array}$ & 22.0 & 20.7 & $5.81 \%$ & 866 & 3 \\
\hline $\begin{array}{l}95 / 17 / 12- \\
97 / 17 / 06\end{array}$ & $\begin{array}{l}-0.375 \\
-1.160 \\
-2.054\end{array}$ & $\begin{array}{l}-0.750 \\
-1.607\end{array}$ & 11.1 & 10.8 & $3.01 \%$ & 548 & 1 \\
\hline $\begin{array}{l}97 / 18 / 06- \\
98 / 02 / 05\end{array}$ & $\begin{array}{l}-0.231 \\
-0.753 \\
-1.337 \\
-1.986\end{array}$ & $\begin{array}{l}-0.477 \\
-1.040 \\
-1.658\end{array}$ & 20.0 & 18.7 & $6.63 \%$ & 318 & 3 \\
\hline $\begin{array}{l}98 / 03 / 05- \\
98 / 31 / 12\end{array}$ & $\begin{array}{l}-0.277 \\
-0.861 \\
-1.614\end{array}$ & $\begin{array}{l}-0.566 \\
-1.223 \\
-2.052\end{array}$ & 20.4 & 19.1 & $5.96 \%$ & 242 & 2 \\
\hline $\begin{array}{l}99 / 01 / 01- \\
01 / 31 / 03\end{array}$ & $\begin{array}{l}-0.352 \\
-1.130 \\
-2.036 \\
-3.129\end{array}$ & $\begin{array}{l}-0.723 \\
-1.567 \\
-2.549\end{array}$ & 34.6 & 33.6 & $2.81 \%$ & 820 & 2 \\
\hline
\end{tabular}


Table XIX: The German Mark against the ECU

\begin{tabular}{|c|c|c|c|c|c|c|c|c|c|c|}
\hline $\begin{array}{l}\text { Time } \\
\text { period }\end{array}$ & \multicolumn{2}{|c|}{$\sum \lambda_{i}$} & $\begin{array}{l}s\left(\bar{\lambda}_{1}\right) \\
s(\widetilde{\lambda})\end{array}$ & $\begin{array}{l}\text { Vol. rate } \\
\left(\times 10^{-6}\right)\end{array}$ & $v$ & $\begin{array}{l}\text { Vol. shock } \\
\left(\times 10^{-6}\right)\end{array}$ & $x$ & $\begin{array}{l}\text { Expl. } \\
\text { vol. }\end{array}$ & \multicolumn{2}{|c|}{ \# obs. $d$} \\
\hline $\begin{array}{l}90 / 02 / 01- \\
91 / 10 / 12\end{array}$ & $\begin{array}{l}-0.765 \\
-2.720\end{array}$ & -1.729 & & 0.428 & & 0.412 & & $3.72 \%$ & 707 & 3 \\
\hline $\begin{array}{l}91 / 11 / 12- \\
92 / 02 / 06\end{array}$ & $\begin{array}{l}-0.294 \\
-0.951 \\
-1.735 \\
-2.745\end{array}$ & $\begin{array}{l}-0.597 \\
-1.335 \\
-2.182\end{array}$ & $\begin{array}{l}1.02 \\
1.07\end{array}$ & 0.183 & 0.32 & 0.134 & 0.26 & $26.58 \%$ & 174 & 3 \\
\hline $\begin{array}{l}92 / 03 / 06- \\
93 / 01 / 08\end{array}$ & $\begin{array}{l}-0.239 \\
-0.772 \\
-1.574 \\
-2.751\end{array}$ & $\begin{array}{l}-0.479 \\
-1.063 \\
-2.094\end{array}$ & $\begin{array}{l}0.10 \\
0.19\end{array}$ & 2.86 & 17.3 & 2.42 & 18.3 & $15.47 \%$ & 424 & 3 \\
\hline $\begin{array}{l}93 / 02 / 08- \\
95 / 16 / 12\end{array}$ & $\begin{array}{l}-0.404 \\
-1.315 \\
-2.346 \\
-3.480\end{array}$ & $\begin{array}{l}-0.845 \\
-1.818 \\
-2.892\end{array}$ & $\begin{array}{l}11.4 \\
6.74\end{array}$ & 1.88 & 0.94 & 1.76 & 1.07 & $6.23 \%$ & 866 & 3 \\
\hline $\begin{array}{l}95 / 17 / 12- \\
97 / 17 / 06\end{array}$ & -2 . & & $\begin{array}{l}3.27 \\
2.63\end{array}$ & 1.08 & 1.23 & 1.03 & 1.26 & $4.25 \%$ & 548 & 3 \\
\hline $\begin{array}{l}97 / 18 / 06- \\
98 / 02 / 05\end{array}$ & $\begin{array}{l}-0.238 \\
-0.762 \\
-1.388 \\
-2.119\end{array}$ & $\begin{array}{l}-0.489 \\
-1.055 \\
-1.751\end{array}$ & $\begin{array}{l}0.25 \\
0.31\end{array}$ & 0.462 & 0.26 & 0.429 & 0.26 & $6.99 \%$ & 318 & 3 \\
\hline $\begin{array}{l}98 / 03 / 05- \\
98 / 31 / 12\end{array}$ & $\begin{array}{l}-0.330 \\
-1.268\end{array}$ & $\begin{array}{l}-0.663 \\
-1.885\end{array}$ & $\begin{array}{l}1.29 \\
1.27\end{array}$ & 0.582 & 1.33 & 0.485 & 1.20 & $16.77 \%$ & 242 & 2 \\
\hline
\end{tabular}


Table XX: The German Mark against the U.S. Dollar

\begin{tabular}{|c|c|c|c|c|c|c|c|}
\hline $\begin{array}{l}\text { Time } \\
\text { period }\end{array}$ & \multicolumn{2}{|c|}{$\sum \lambda_{i}$} & $\begin{array}{l}\text { Vol. rate } \\
\left(\times 10^{-6}\right)\end{array}$ & $\begin{array}{l}\text { Vol. shock } \\
\left(\times 10^{-6}\right)\end{array}$ & $\begin{array}{l}\text { Expl. } \\
\text { vol. }\end{array}$ & \multicolumn{2}{|c|}{ \# obs. $d$} \\
\hline $\begin{array}{l}90 / 02 / 01- \\
91 / 10 / 12\end{array}$ & $\begin{array}{l}-0.669 \\
-2.252\end{array}$ & $\begin{array}{l}-1.408 \\
-3.822\end{array}$ & 32.5 & 30.9 & $5.00 \%$ & 707 & 3 \\
\hline $\begin{array}{l}91 / 11 / 12- \\
92 / 02 / 06\end{array}$ & $\begin{array}{l}-0.251 \\
-0.898 \\
-1.659 \\
-2.692\end{array}$ & $\begin{array}{l}-0.561 \\
-1.263 \\
-2.123\end{array}$ & 43.2 & 38.8 & $10.04 \%$ & 174 & 3 \\
\hline $\begin{array}{l}92 / 03 / 06- \\
93 / 01 / 08\end{array}$ & \multicolumn{2}{|c|}{-2.079} & 39.0 & 38.2 & $2.01 \%$ & 424 & 2 \\
\hline $\begin{array}{l}93 / 02 / 08- \\
95 / 16 / 12\end{array}$ & $\begin{array}{l}-0.309 \\
-1.024 \\
-1.863\end{array}$ & $\begin{array}{l}-0.647 \\
-1.423 \\
-2.342\end{array}$ & 27.3 & 26.0 & $4.69 \%$ & 866 & 3 \\
\hline $\begin{array}{l}95 / 17 / 12- \\
97 / 17 / 06\end{array}$ & $\begin{array}{l}-0.489 \\
-1.652 \\
-3.124\end{array}$ & $\begin{array}{l}-1.028 \\
-2.348\end{array}$ & 12.7 & 12.1 & $4.82 \%$ & 548 & 3 \\
\hline $\begin{array}{l}97 / 18 / 06- \\
98 / 02 / 05\end{array}$ & $\begin{array}{l}-0.223 \\
-0.753 \\
-1.358 \\
-2.057\end{array}$ & $\begin{array}{l}-0.463 \\
-1.042 \\
-1.686\end{array}$ & 20.7 & 19.2 & $7.67 \%$ & 318 & 3 \\
\hline $\begin{array}{l}98 / 03 / 05- \\
98 / 31 / 12\end{array}$ & $\begin{array}{l}-0.240 \\
-0.830 \\
-1.565 \\
-2.514\end{array}$ & $\begin{array}{l}-0.512 \\
-1.177 \\
-2.003\end{array}$ & 19.6 & 18.1 & $7.66 \%$ & 242 & 2 \\
\hline $\begin{array}{l}99 / 01 / 01- \\
01 / 31 / 03\end{array}$ & -3. & 148 & 34.6 & 34.3 & $0.80 \%$ & 820 & 2 \\
\hline
\end{tabular}


Table XXI: The Irish Punt against the ECU

\begin{tabular}{|c|c|c|c|c|c|c|c|c|c|c|}
\hline $\begin{array}{l}\text { Time } \\
\text { period }\end{array}$ & \multicolumn{2}{|c|}{$\sum \lambda_{i}$} & $\begin{array}{l}s\left(\bar{\lambda}_{1}\right) \\
s(\widetilde{\lambda})\end{array}$ & $\begin{array}{l}\text { Vol. rate } \\
\left(\times 10^{-6}\right)\end{array}$ & $v$ & $\begin{array}{l}\text { Vol. shock } \\
\left(\times 10^{-6}\right)\end{array}$ & $x$ & $\begin{array}{l}\text { Expl. } \\
\text { vol. }\end{array}$ & \# obs. & $d$ \\
\hline $\begin{array}{l}90 / 02 / 01- \\
91 / 10 / 12\end{array}$ & $\begin{array}{l}-0.284 \\
-0.909 \\
-1.658 \\
-2.566\end{array}$ & $\begin{array}{l}-0.568 \\
-1.257 \\
-2.069\end{array}$ & & 5.68 & & 4.17 & & $26.55 \%$ & 707 & 3 \\
\hline $\begin{array}{l}91 / 11 / 12- \\
92 / 02 / 06\end{array}$ & $\begin{array}{l}-0.276 \\
-0.933 \\
-1.773\end{array}$ & $\begin{array}{l}-0.578 \\
-1.326 \\
-2.254\end{array}$ & $\begin{array}{l}9.22 \\
6.91\end{array}$ & 9.24 & 1.55 & 6.76 & 1.69 & $26.84 \%$ & 174 & 3 \\
\hline $\begin{array}{l}92 / 03 / 06- \\
92 / 23 / 09\end{array}$ & $\begin{array}{l}-0.617 \\
-1.969\end{array}$ & -1.263 & $\begin{array}{l}2.22 \\
1.53\end{array}$ & 18.4 & 1.33 & 12.3 & 1.38 & $33.31 \%$ & 112 & 2 \\
\hline $\begin{array}{l}92 / 24 / 09- \\
92 / 31 / 12\end{array}$ & $\begin{array}{l}-0.430 \\
-1.763\end{array}$ & $\begin{array}{l}-0.974 \\
-2.729\end{array}$ & $\begin{array}{l}0.81 \\
1.00\end{array}$ & 20.3 & 1.25 & 15.0 & 1.35 & $26.17 \%$ & 98 & 3 \\
\hline $\begin{array}{l}93 / 01 / 01- \\
93 / 01 / 08\end{array}$ & -0.954 & -2.222 & $\begin{array}{l}1.17 \\
1.28\end{array}$ & 34.2 & 1.29 & 33.3 & 1.56 & $2.52 \%$ & 212 & 1 \\
\hline $\begin{array}{l}93 / 02 / 08- \\
95 / 16 / 12\end{array}$ & $\begin{array}{l}-0.454 \\
-1.437 \\
-2.527 \\
-3.693\end{array}$ & $\begin{array}{l}-0.932 \\
-1.975 \\
-3.095\end{array}$ & $\begin{array}{l}0.06 \\
0.09\end{array}$ & 13.6 & 1.69 & 12.8 & 1.47 & $5.93 \%$ & 866 & 3 \\
\hline $\begin{array}{l}95 / 17 / 12- \\
97 / 17 / 06\end{array}$ & $\begin{array}{l}-0.380 \\
-1.180 \\
-2.117\end{array}$ & $\begin{array}{l}-0.770 \\
-1.622 \\
-2.631\end{array}$ & $\begin{array}{l}5.09 \\
3.94\end{array}$ & 8.24 & 0.88 & 7.98 & 0.96 & $3.19 \%$ & 548 & 3 \\
\hline $\begin{array}{l}97 / 18 / 06- \\
98 / 02 / 05\end{array}$ & -2 & 589 & $\begin{array}{l}2.54 \\
2.68\end{array}$ & 8.60 & 0.49 & 8.29 & 0.48 & $3.55 \%$ & 318 & 2 \\
\hline $\begin{array}{l}98 / 03 / 05- \\
98 / 31 / 12\end{array}$ & $\begin{array}{l}-0.263 \\
-0.932 \\
-1.742 \\
-2.804\end{array}$ & $\begin{array}{l}-0.571 \\
-1.321 \\
-2.169\end{array}$ & $\begin{array}{l}0.10 \\
0.12\end{array}$ & 5.26 & 0.77 & 3.39 & 0.52 & $35.64 \%$ & 242 & 3 \\
\hline
\end{tabular}


Table XXII: The Irish Punt against the U.S. Dollar

\begin{tabular}{|c|c|c|c|c|c|c|c|}
\hline $\begin{array}{l}\text { Time } \\
\text { period }\end{array}$ & \multicolumn{2}{|c|}{$\sum \lambda_{i}$} & $\begin{array}{l}\text { Vol. rate } \\
\left(\times 10^{-6}\right)\end{array}$ & $\begin{array}{l}\text { Vol. shock } \\
\left(\times 10^{-6}\right)\end{array}$ & $\begin{array}{l}\text { Expl. } \\
\text { vol. }\end{array}$ & \multicolumn{2}{|c|}{ \# obs. $d$} \\
\hline $\begin{array}{l}90 / 02 / 01- \\
91 / 10 / 12\end{array}$ & -1.661 & -3.491 & 34.8 & 34.2 & $1.63 \%$ & 707 & 3 \\
\hline $\begin{array}{l}91 / 11 / 12- \\
92 / 02 / 06\end{array}$ & $\begin{array}{l}-0.175 \\
-0.571 \\
-1.189\end{array}$ & $\begin{array}{l}-0.374 \\
-0.872 \\
-1.553\end{array}$ & 36.6 & 32.9 & $10.22 \%$ & 174 & 3 \\
\hline $\begin{array}{l}92 / 03 / 06- \\
92 / 23 / 09\end{array}$ & $\begin{array}{l}-0.176 \\
-0.554 \\
-1.110 \\
-2.068\end{array}$ & $\begin{array}{l}-0.344 \\
-0.821 \\
-1.457\end{array}$ & 54.9 & 43.5 & $20.82 \%$ & 112 & 2 \\
\hline $\begin{array}{l}92 / 24 / 09- \\
92 / 31 / 12\end{array}$ & $\begin{array}{l}-0.151 \\
-0.612 \\
-1.280 \\
-2.153\end{array}$ & $\begin{array}{l}-0.326 \\
-0.930 \\
-1.698\end{array}$ & 48.4 & 39.4 & $18.72 \%$ & 98 & 2 \\
\hline $\begin{array}{l}93 / 01 / 01- \\
93 / 01 / 08\end{array}$ & $\begin{array}{l}-0.287 \\
-0.966 \\
-1.776 \\
-2.729\end{array}$ & $\begin{array}{l}-0.602 \\
-1.368 \\
-2.205\end{array}$ & 63.3 & 55.9 & $11.58 \%$ & 212 & 3 \\
\hline $\begin{array}{l}93 / 02 / 08- \\
95 / 16 / 12\end{array}$ & -2 . & & 14.9 & 14.6 & $1.92 \%$ & 866 & 3 \\
\hline $\begin{array}{l}95 / 17 / 12- \\
97 / 17 / 06\end{array}$ & $\begin{array}{l}-0.348 \\
-1.133 \\
-2.046 \\
-3.126\end{array}$ & $\begin{array}{l}-0.725 \\
-1.579 \\
-2.565\end{array}$ & 10.3 & 9.52 & $7.13 \%$ & 548 & 3 \\
\hline $\begin{array}{l}97 / 18 / 06- \\
98 / 02 / 05\end{array}$ & -0.933 & -1.965 & 21.8 & 20.8 & $4.72 \%$ & 318 & 3 \\
\hline $\begin{array}{l}98 / 03 / 05- \\
98 / 31 / 12\end{array}$ & -0.932 & -2.439 & 17.3 & 16.5 & $4.59 \%$ & 242 & 3 \\
\hline $\begin{array}{l}99 / 01 / 01- \\
01 / 31 / 03\end{array}$ & -3 . & & 34.6 & 34.3 & $0.80 \%$ & 820 & 2 \\
\hline
\end{tabular}


Table XXIII: The Italian Lira against the ECU

\begin{tabular}{|c|c|c|c|c|c|c|c|c|c|c|}
\hline $\begin{array}{l}\text { Time } \\
\text { period }\end{array}$ & \multicolumn{2}{|c|}{$\sum \lambda_{i}$} & $\begin{array}{l}s\left(\bar{\lambda}_{1}\right) \\
s(\widetilde{\lambda})\end{array}$ & $\begin{array}{l}\text { Vol. rate } \\
\left(\times 10^{-6}\right)\end{array}$ & $v$ & $\begin{array}{l}\text { Vol. shock } \\
\left(\times 10^{-6}\right)\end{array}$ & $x$ & $\begin{array}{l}\text { Expl. } \\
\text { vol. }\end{array}$ & \# obs. & $d$ \\
\hline $\begin{array}{l}90 / 08 / 01- \\
91 / 10 / 12\end{array}$ & $\begin{array}{l}-0.451 \\
-1.421 \\
-2.535 \\
-3.836\end{array}$ & $\begin{array}{l}-0.922 \\
-1.966 \\
-3.161\end{array}$ & & 0.959 & & 0.855 & & $10.82 \%$ & 701 & 3 \\
\hline $\begin{array}{l}91 / 11 / 12- \\
92 / 02 / 06\end{array}$ & $\begin{array}{l}-0.165 \\
-0.723 \\
-1.808\end{array}$ & $\begin{array}{l}-0.378 \\
-1.168 \\
-2.571\end{array}$ & $\begin{array}{l}1.52 \\
2.32\end{array}$ & 0.234 & 0.18 & 0.210 & 0.21 & $10.05 \%$ & 174 & 3 \\
\hline $\begin{array}{l}92 / 03 / 06- \\
92 / 13 / 09\end{array}$ & $\begin{array}{l}-0.066 \\
-0.358 \\
-0.863\end{array}$ & $\begin{array}{l}-0.176 \\
-0.539 \\
-1.148\end{array}$ & $\begin{array}{l}0.16 \\
0.24\end{array}$ & 0.504 & 2.28 & 0.407 & 1.89 & $19.23 \%$ & 102 & 2 \\
\hline $\begin{array}{l}92 / 14 / 09- \\
93 / 01 / 08\end{array}$ & $\begin{array}{l}-0.326 \\
-1.063 \\
-1.883 \\
-2.870\end{array}$ & $\begin{array}{l}-0.691 \\
-1.458 \\
-2.344\end{array}$ & $\begin{array}{l}7.37 \\
3.01\end{array}$ & 27.0 & 43.7 & 22.5 & 45.1 & $16.51 \%$ & 321 & 3 \\
\hline $\begin{array}{l}93 / 02 / 08- \\
95 / 16 / 12\end{array}$ & $\begin{array}{l}-0.268 \\
-0.856 \\
-1.515 \\
-2.272\end{array}$ & $\begin{array}{l}-0.536 \\
-1.177 \\
-1.881\end{array}$ & $\begin{array}{l}0.72 \\
0.73\end{array}$ & 15.5 & 1.20 & 14.1 & 1.25 & $8.68 \%$ & 866 & 3 \\
\hline $\begin{array}{l}95 / 17 / 12- \\
96 / 23 / 11\end{array}$ & $\begin{array}{l}-0.305 \\
-1.070 \\
-1.994\end{array}$ & $\begin{array}{l}-0.664 \\
-1.493 \\
-2.667\end{array}$ & $\begin{array}{l}0.36 \\
0.55\end{array}$ & 5.94 & 1.16 & 5.33 & 1.12 & $10.34 \%$ & 342 & 3 \\
\hline $\begin{array}{l}96 / 24 / 11- \\
97 / 17 / 06\end{array}$ & $\begin{array}{l}-0.927 \\
-3.029\end{array}$ & -1.894 & $\begin{array}{l}5.57 \\
3.48\end{array}$ & 3.09 & 0.29 & 2.91 & 0.31 & $5.94 \%$ & 205 & 3 \\
\hline $\begin{array}{l}97 / 18 / 06- \\
98 / 02 / 05\end{array}$ & $\begin{array}{l}-0.335 \\
-1.186 \\
-2.301\end{array}$ & $\begin{array}{l}-0.734 \\
-1.713\end{array}$ & $\begin{array}{l}1.11 \\
0.88\end{array}$ & 1.11 & 0.27 & 1.03 & 0.28 & $7.19 \%$ & 318 & 2 \\
\hline $\begin{array}{l}98 / 03 / 05- \\
98 / 31 / 12\end{array}$ & $\begin{array}{l}-0.285 \\
-1.134 \\
-2.468\end{array}$ & $\begin{array}{l}-0.638 \\
-1.750 \\
-3.259\end{array}$ & $\begin{array}{l}0.14 \\
0.35\end{array}$ & 1.71 & 1.33 & 1.19 & 0.92 & $30.44 \%$ & 242 & 3 \\
\hline
\end{tabular}


Table XXIV: The Italian Lira against the U.S. Dollar

\begin{tabular}{|c|c|c|c|c|c|c|c|}
\hline $\begin{array}{l}\text { Time } \\
\text { period }\end{array}$ & \multicolumn{2}{|c|}{$\sum \lambda_{i}$} & $\begin{array}{l}\text { Vol. rate } \\
\left(\times 10^{-6}\right)\end{array}$ & $\begin{array}{l}\text { Vol. shock } \\
\left(\times 10^{-6}\right)\end{array}$ & $\begin{array}{l}\text { Expl. } \\
\text { vol. }\end{array}$ & \# obs. & $d$ \\
\hline $\begin{array}{l}90 / 08 / 01- \\
91 / 10 / 12\end{array}$ & $\begin{array}{l}-0.789 \\
-2.631\end{array}$ & $\begin{array}{l}-1.651 \\
-3.741\end{array}$ & 28.4 & 27.7 & $2.41 \%$ & 701 & 3 \\
\hline $\begin{array}{l}91 / 11 / 12- \\
92 / 02 / 06\end{array}$ & $\begin{array}{l}-0.190 \\
-0.712 \\
-1.433\end{array}$ & $\begin{array}{l}-0.442 \\
-1.037 \\
-1.892\end{array}$ & 39.3 & 33.1 & $15.88 \%$ & 174 & 3 \\
\hline $\begin{array}{l}92 / 03 / 06- \\
92 / 13 / 09\end{array}$ & $\begin{array}{l}-0.461 \\
-1.729\end{array}$ & -0.938 & 37.1 & 34.0 & $8.47 \%$ & 102 & 2 \\
\hline $\begin{array}{l}92 / 14 / 09- \\
93 / 01 / 08\end{array}$ & $\begin{array}{l}-0.309 \\
-1.028 \\
-1.897\end{array}$ & $\begin{array}{l}-0.659 \\
-1.434 \\
-2.460\end{array}$ & 45.5 & 41.7 & $8.35 \%$ & 321 & 3 \\
\hline $\begin{array}{l}93 / 02 / 08- \\
95 / 16 / 12\end{array}$ & $\begin{array}{l}-0.355 \\
-1.170 \\
-2.080 \\
-3.132\end{array}$ & $\begin{array}{l}-0.749 \\
-1.606 \\
-2.589\end{array}$ & 21.7 & 20.9 & $3.87 \%$ & 866 & 3 \\
\hline $\begin{array}{l}95 / 17 / 12- \\
96 / 23 / 11\end{array}$ & -1.117 & -2.234 & 7.17 & 7.08 & $1.15 \%$ & 342 & $1^{*}$ \\
\hline $\begin{array}{l}96 / 24 / 11- \\
97 / 17 / 06\end{array}$ & $\begin{array}{l}-0.609 \\
-2.190\end{array}$ & -1.339 & 12.9 & 12.3 & $4.84 \%$ & 205 & 2 \\
\hline $\begin{array}{l}97 / 18 / 06- \\
98 / 02 / 05\end{array}$ & $\begin{array}{l}-0.199 \\
-0.716 \\
-1.372 \\
-2.653\end{array}$ & $\begin{array}{l}-0.446 \\
-1.013 \\
-1.888\end{array}$ & 17.4 & 15.6 & $10.21 \%$ & 318 & 3 \\
\hline $\begin{array}{l}98 / 03 / 05- \\
98 / 31 / 12\end{array}$ & -1.227 & -2.587 & 20.2 & 19.5 & $3.25 \%$ & 242 & 2 \\
\hline $\begin{array}{l}99 / 01 / 01- \\
01 / 31 / 03\end{array}$ & $\begin{array}{l}-0.352 \\
-1.130 \\
-2.037 \\
-3.131\end{array}$ & $\begin{array}{l}-0.724 \\
-1.567 \\
-2.550\end{array}$ & 34.6 & 33.6 & $2.81 \%$ & 820 & 2 \\
\hline $\begin{array}{l}\text { ote: See Tabl } \\
\text { See note in I }\end{array}$ & e. & & & & & & \\
\hline
\end{tabular}


Table XXV: The Portuguese Escudo against the ECU

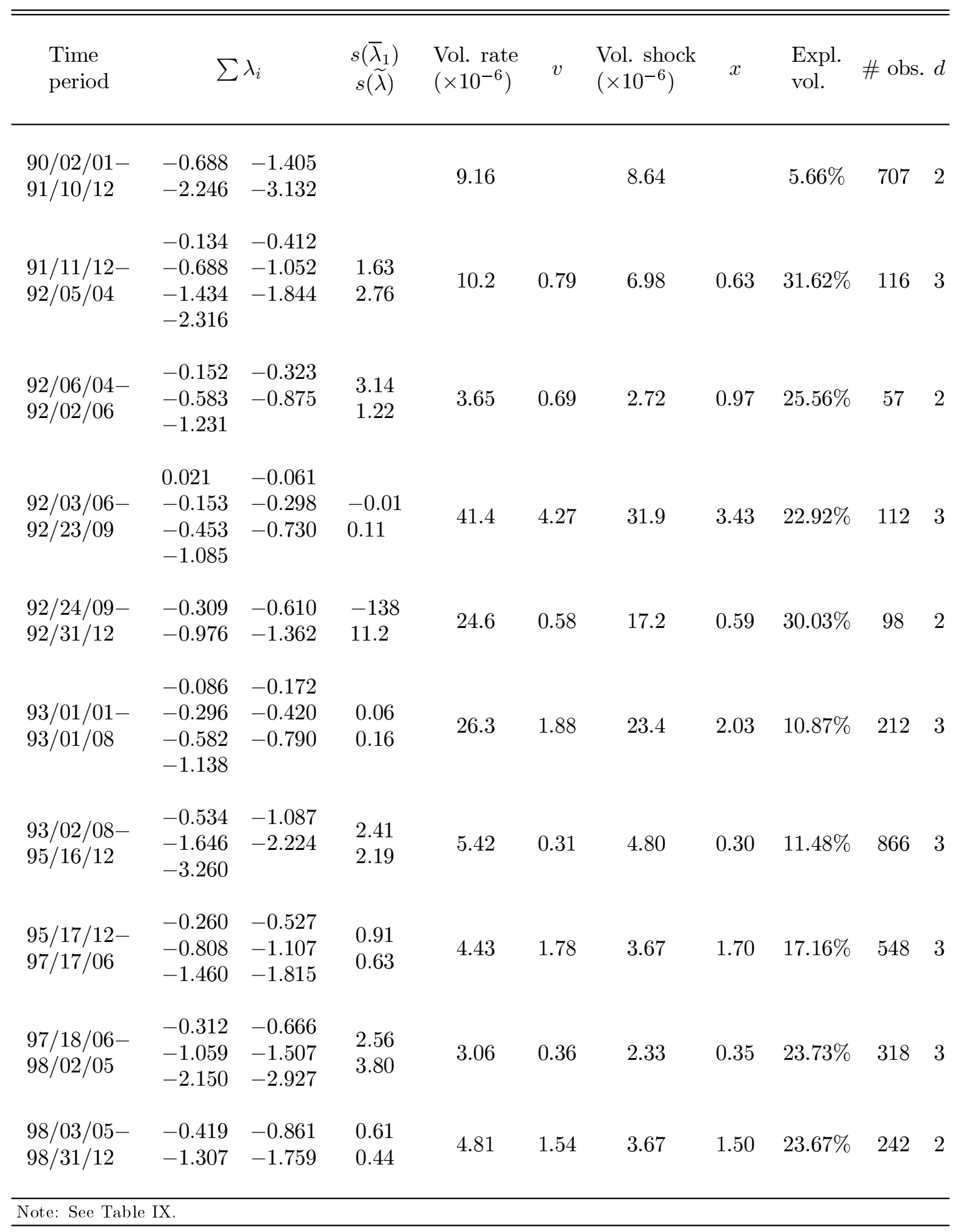


Table XXVI: The Portuguese Escudo against the U.S. Dollar

\begin{tabular}{|c|c|c|c|c|c|c|c|}
\hline $\begin{array}{l}\text { Time } \\
\text { period }\end{array}$ & \multicolumn{2}{|c|}{$\sum \lambda_{i}$} & $\begin{array}{l}\text { Vol. rate } \\
\left(\times 10^{-6}\right)\end{array}$ & $\begin{array}{l}\text { Vol. shock } \\
\left(\times 10^{-6}\right)\end{array}$ & $\begin{array}{l}\text { Expl. } \\
\text { vol. }\end{array}$ & \# obs. & $d$ \\
\hline $\begin{array}{l}90 / 02 / 01- \\
91 / 10 / 12\end{array}$ & -1.780 & -3.746 & 31.5 & 31.1 & $1.17 \%$ & 707 & 2 \\
\hline $\begin{array}{l}91 / 11 / 12- \\
92 / 05 / 04\end{array}$ & $\begin{array}{l}-0.213 \\
-0.770 \\
-1.435\end{array}$ & $\begin{array}{l}-0.471 \\
-1.096\end{array}$ & 44.5 & 39.7 & $10.87 \%$ & 116 & $3^{*}$ \\
\hline $\begin{array}{l}92 / 06 / 04- \\
92 / 02 / 06\end{array}$ & $\begin{array}{l}-0.077 \\
-0.284 \\
-0.688\end{array}$ & $\begin{array}{l}-0.173 \\
-0.460 \\
-1.050\end{array}$ & 23.0 & 15.9 & $30.76 \%$ & 57 & 2 \\
\hline $\begin{array}{l}92 / 03 / 06- \\
92 / 23 / 09\end{array}$ & -0.855 & -2.019 & 61.1 & 54.4 & $10.95 \%$ & 112 & 2 \\
\hline $\begin{array}{l}92 / 24 / 09- \\
92 / 31 / 12\end{array}$ & $\begin{array}{l}-0.091 \\
-0.316 \\
-0.706 \\
-1.383\end{array}$ & $\begin{array}{l}-0.188 \\
-0.461 \\
-1.005\end{array}$ & 62.3 & 49.7 & $20.18 \%$ & 98 & 3 \\
\hline $\begin{array}{l}93 / 01 / 01- \\
93 / 01 / 08\end{array}$ & $\begin{array}{l}-0.407 \\
-1.791\end{array}$ & -1.046 & 35.4 & 33.3 & $5.90 \%$ & 212 & 3 \\
\hline $\begin{array}{l}93 / 02 / 08- \\
95 / 16 / 12\end{array}$ & $\begin{array}{l}-1.048 \\
-3.287\end{array}$ & -2.143 & 23.5 & 23.1 & $1.68 \%$ & 866 & 3 \\
\hline $\begin{array}{l}95 / 17 / 12- \\
97 / 17 / 06\end{array}$ & $\begin{array}{l}-0.563 \\
-1.964 \\
-3.684\end{array}$ & $\begin{array}{l}-1.209 \\
-2.765 \\
-4.859\end{array}$ & 10.8 & 10.4 & $4.00 \%$ & 548 & 3 \\
\hline $\begin{array}{l}97 / 18 / 06- \\
98 / 02 / 05\end{array}$ & $\begin{array}{l}-0.264 \\
-0.849 \\
-1.563 \\
-2.405\end{array}$ & $\begin{array}{l}-0.539 \\
-1.190 \\
-1.968\end{array}$ & 20.6 & 19.0 & $7.83 \%$ & 318 & 3 \\
\hline $\begin{array}{l}98 / 03 / 05- \\
98 / 31 / 12\end{array}$ & $\begin{array}{l}-0.584 \\
-2.016\end{array}$ & $\begin{array}{l}-1.280 \\
-2.843\end{array}$ & 21.0 & 19.9 & $5.15 \%$ & 242 & $3^{*}$ \\
\hline $\begin{array}{l}99 / 01 / 01- \\
01 / 31 / 03\end{array}$ & $\begin{array}{l}-0.352 \\
-1.130 \\
-2.036 \\
-3.131\end{array}$ & $\begin{array}{l}-0.724 \\
-1.567 \\
-2.548\end{array}$ & 34.6 & 33.6 & $2.81 \%$ & 820 & 2 \\
\hline te: See Tabl & & & & & & & \\
\hline
\end{tabular}


Table XXVII: The Spanish Peseta against the ECU

\begin{tabular}{|c|c|c|c|c|c|c|c|c|c|c|}
\hline $\begin{array}{l}\text { Time } \\
\text { period }\end{array}$ & \multicolumn{2}{|c|}{$\sum \lambda_{i}$} & $\begin{array}{l}s\left(\bar{\lambda}_{1}\right) \\
s(\widetilde{\lambda})\end{array}$ & $\begin{array}{l}\text { Vol. rate } \\
\left(\times 10^{-6}\right)\end{array}$ & $v$ & $\begin{array}{l}\text { Vol. shock } \\
\left(\times 10^{-6}\right)\end{array}$ & $x$ & $\begin{array}{l}\text { Expl. } \\
\text { vol. }\end{array}$ & \# obs. & $d$ \\
\hline $\begin{array}{l}90 / 02 / 01- \\
91 / 10 / 12\end{array}$ & $\begin{array}{l}-0.581 \\
-1.944 \\
-3.684\end{array}$ & $\begin{array}{l}-1.211 \\
-2.755 \\
-4.756\end{array}$ & & 5.94 & & 5.37 & & $9.61 \%$ & 707 & 3 \\
\hline $\begin{array}{l}91 / 11 / 12- \\
92 / 02 / 06\end{array}$ & $\begin{array}{l}-0.206 \\
-0.875 \\
-1.621 \\
-2.588\end{array}$ & $\begin{array}{l}-0.513 \\
-1.218 \\
-2.083\end{array}$ & $\begin{array}{l}3.22 \\
2.82\end{array}$ & 6.07 & 0.88 & 4.52 & 0.81 & $25.49 \%$ & 174 & 3 \\
\hline $\begin{array}{l}92 / 03 / 06- \\
92 / 22 / 09\end{array}$ & \multicolumn{2}{|c|}{-2.536} & $\begin{array}{l}6.46 \\
3.68\end{array}$ & 37.9 & 2.51 & 37.6 & 3.72 & $0.63 \%$ & 111 & $1^{*}$ \\
\hline $\begin{array}{l}92 / 23 / 09- \\
92 / 31 / 12\end{array}$ & \multicolumn{2}{|c|}{-2.726} & $\begin{array}{l}0.17 \\
0.26\end{array}$ & 10.3 & 0.57 & 10.2 & 0.46 & $0.43 \%$ & 99 & $1^{*}$ \\
\hline $\begin{array}{l}93 / 01 / 01- \\
93 / 01 / 08\end{array}$ & \multicolumn{2}{|c|}{-2.431} & $\begin{array}{l}7.78 \\
4.89\end{array}$ & 20.6 & 2.38 & 20.5 & 2.60 & $0.77 \%$ & 212 & $1^{*}$ \\
\hline $\begin{array}{l}93 / 02 / 08- \\
95 / 16 / 12\end{array}$ & \multicolumn{2}{|c|}{-3.608} & $\begin{array}{l}0.11 \\
0.17\end{array}$ & 23.6 & 1.12 & 16.3 & 0.87 & $31.16 \%$ & 866 & 3 \\
\hline $\begin{array}{l}95 / 17 / 12- \\
97 / 17 / 06\end{array}$ & $\begin{array}{l}-0.437 \\
-1.399 \\
-2.718\end{array}$ & $\begin{array}{l}-0.874 \\
-1.924\end{array}$ & $\begin{array}{l}1.51 \\
1.38\end{array}$ & 4.06 & 0.63 & 3.63 & 0.69 & $10.51 \%$ & 548 & 1 \\
\hline $\begin{array}{l}97 / 18 / 06- \\
98 / 02 / 05\end{array}$ & -0.660 & -1.358 & $\begin{array}{l}1.74 \\
1.62\end{array}$ & 3.06 & 0.39 & 2.56 & 0.38 & $16.33 \%$ & 318 & 3 \\
\hline $\begin{array}{l}98 / 03 / 05- \\
98 / 31 / 12\end{array}$ & $\begin{array}{l}-0.310 \\
-1.004 \\
-1.813\end{array}$ & $\begin{array}{l}-0.655 \\
-1.406\end{array}$ & $\begin{array}{l}0.14 \\
0.16\end{array}$ & 9.73 & 3.06 & 4.67 & 1.76 & $52.01 \%$ & 242 & 3 \\
\hline $\begin{array}{l}\text { See Ta } \\
\text { note in }\end{array}$ & & & & & & & & & & \\
\hline
\end{tabular}


Table XXVIII: The Spanish Peseta against the U.S. Dollar

\begin{tabular}{|c|c|c|c|c|c|c|c|}
\hline $\begin{array}{l}\text { Time } \\
\text { period }\end{array}$ & \multicolumn{2}{|c|}{$\sum \lambda_{i}$} & $\begin{array}{l}\text { Vol. rate } \\
\left(\times 10^{-6}\right)\end{array}$ & $\begin{array}{l}\text { Vol. shock } \\
\left(\times 10^{-6}\right)\end{array}$ & $\begin{array}{l}\text { Expl. } \\
\text { vol. }\end{array}$ & \# obs. & $d$ \\
\hline $\begin{array}{l}90 / 02 / 01- \\
91 / 10 / 12\end{array}$ & -1.737 & -3.648 & 33.2 & 32.9 & $0.99 \%$ & 707 & 2 \\
\hline $\begin{array}{l}91 / 11 / 12- \\
92 / 02 / 06\end{array}$ & $\begin{array}{l}-0.191 \\
-0.720 \\
-1.507\end{array}$ & $\begin{array}{l}-0.420 \\
-1.045\end{array}$ & 38.4 & 34.3 & $10.44 \%$ & 174 & 3 \\
\hline $\begin{array}{l}92 / 03 / 06- \\
92 / 22 / 09\end{array}$ & $\begin{array}{l}-0.364 \\
-1.686\end{array}$ & -0.918 & 95.4 & 76.6 & $19.66 \%$ & 111 & 3 \\
\hline $\begin{array}{l}92 / 23 / 09- \\
92 / 31 / 12\end{array}$ & \multicolumn{2}{|c|}{-2.346} & 45.6 & 45.2 & $0.95 \%$ & 99 & $1^{*}$ \\
\hline $\begin{array}{l}93 / 01 / 01- \\
93 / 01 / 08\end{array}$ & $\begin{array}{l}-0.269 \\
-1.143\end{array}$ & $\begin{array}{l}-0.655 \\
-1.711\end{array}$ & 38.4 & 34.9 & $9.03 \%$ & 212 & 3 \\
\hline $\begin{array}{l}93 / 02 / 08- \\
95 / 16 / 12\end{array}$ & \multicolumn{2}{|c|}{-3.735} & 39.4 & 32.0 & $18.83 \%$ & 866 & 3 \\
\hline $\begin{array}{l}95 / 17 / 12- \\
97 / 17 / 06\end{array}$ & $\begin{array}{l}-0.299 \\
-0.948 \\
-1.733 \\
-2.859\end{array}$ & $\begin{array}{l}-0.622 \\
-1.320 \\
-2.192\end{array}$ & 10.7 & 10.3 & $4.09 \%$ & 548 & 3 \\
\hline $\begin{array}{l}97 / 18 / 06- \\
98 / 02 / 05\end{array}$ & $\begin{array}{l}-0.259 \\
-0.826 \\
-1.467 \\
-2.209\end{array}$ & $\begin{array}{l}-0.536 \\
-1.133 \\
-1.828\end{array}$ & 20.5 & 19.0 & $6.95 \%$ & 318 & 2 \\
\hline $\begin{array}{l}98 / 03 / 05- \\
98 / 31 / 12\end{array}$ & -0.847 & -2.161 & 21.3 & 19.7 & $7.44 \%$ & 242 & 3 \\
\hline $\begin{array}{l}99 / 01 / 01- \\
01 / 31 / 03\end{array}$ & $\begin{array}{l}-0.352 \\
-1.130 \\
-2.037 \\
-3.133\end{array}$ & $\begin{array}{l}-0.724 \\
-1.567 \\
-2.550\end{array}$ & 34.6 & 33.6 & $2.81 \%$ & 820 & 2 \\
\hline $\begin{array}{l}\text { te: See Tabl } \\
\text { see note in } T\end{array}$ & & & & & & & \\
\hline
\end{tabular}


Table XXIX: The British Pound against the ECU and the Euro

\begin{tabular}{|c|c|c|c|c|c|c|c|c|c|c|}
\hline $\begin{array}{l}\text { Time } \\
\text { period }\end{array}$ & \multicolumn{2}{|c|}{$\sum \lambda_{i}$} & $\begin{array}{c}s\left(\bar{\lambda}_{1}\right) \\
s(\widetilde{\lambda})\end{array}$ & $\begin{array}{l}\text { Vol. rate } \\
\left(\times 10^{-6}\right)\end{array}$ & $v$ & $\begin{array}{l}\text { Vol. shock } \\
\left(\times 10^{-6}\right)\end{array}$ & $x$ & $\begin{array}{l}\text { Expl. } \\
\text { vol. }\end{array}$ & \# obs. & $d$ \\
\hline $\begin{array}{l}90 / 08 / 10- \\
91 / 10 / 12\end{array}$ & $\begin{array}{l}-0.234 \\
-0.796 \\
-1.486 \\
-2.701\end{array}$ & $\begin{array}{l}-0.487 \\
-1.113 \\
-1.861\end{array}$ & & 21.5 & & 16.5 & & $23.18 \%$ & 428 & 3 \\
\hline $\begin{array}{l}91 / 11 / 12- \\
92 / 02 / 06\end{array}$ & $\begin{array}{l}-0.287 \\
-1.141 \\
-2.343\end{array}$ & $\begin{array}{l}-0.660 \\
-1.671\end{array}$ & $\begin{array}{l}1.86 \\
1.97\end{array}$ & 17.5 & 0.69 & 11.5 & 0.62 & $34.13 \%$ & 174 & 3 \\
\hline $\begin{array}{l}92 / 03 / 06- \\
92 / 16 / 09\end{array}$ & $\begin{array}{l}0.024 \\
-0.202 \\
-0.615 \\
-1.276\end{array}$ & $\begin{array}{l}-0.068 \\
-0.382 \\
-0.909\end{array}$ & $\begin{array}{l}-0.15 \\
0.38\end{array}$ & 33.9 & 1.87 & 11.5 & 1.03 & $66.02 \%$ & 105 & 3 \\
\hline $\begin{array}{l}92 / 17 / 09- \\
93 / 01 / 08\end{array}$ & $\begin{array}{l}-0.346 \\
-1.201 \\
-2.267\end{array}$ & $\begin{array}{l}-0.753 \\
-1.711 \\
-2.941\end{array}$ & $\begin{array}{l}-6.25 \\
3.13\end{array}$ & 31.3 & 0.80 & 28.6 & 1.92 & $8.82 \%$ & 318 & 3 \\
\hline $\begin{array}{l}93 / 02 / 08- \\
95 / 16 / 12\end{array}$ & $\begin{array}{l}-0.442 \\
-1.428 \\
-2.529 \\
-3.741\end{array}$ & $\begin{array}{l}-0.918 \\
-1.968 \\
-3.115\end{array}$ & $\begin{array}{l}0.46 \\
0.39\end{array}$ & 15.1 & 1.54 & 14.1 & 1.45 & $7.06 \%$ & 866 & 3 \\
\hline $\begin{array}{l}95 / 17 / 12- \\
97 / 17 / 06\end{array}$ & $\begin{array}{l}-0.453 \\
-1.419 \\
-2.517 \\
-4.393\end{array}$ & $\begin{array}{l}-0.914 \\
-1.957 \\
-3.138\end{array}$ & $\begin{array}{l}0.90 \\
1.23\end{array}$ & 10.5 & 0.98 & 9.98 & 1.01 & $5.30 \%$ & 548 & 3 \\
\hline $\begin{array}{l}97 / 18 / 06- \\
98 / 02 / 05\end{array}$ & -3 . & & $\begin{array}{l}2.64 \\
2.09\end{array}$ & 15.4 & 0.89 & 15.4 & 0.94 & $0.22 \%$ & 318 & 1 \\
\hline $\begin{array}{l}98 / 03 / 05- \\
98 / 31 / 12\end{array}$ & $\begin{array}{l}-0.280 \\
-0.932 \\
-1.754 \\
-4.096\end{array}$ & $\begin{array}{l}-0.591 \\
-1.328 \\
-2.267\end{array}$ & $\begin{array}{l}0.51 \\
0.80\end{array}$ & 11.8 & 0.99 & 10.9 & 0.99 & $8.01 \%$ & 242 & 2 \\
\hline $\begin{array}{l}99 / 01 / 01- \\
01 / 31 / 03\end{array}$ & $\begin{array}{l}-0.442 \\
-1.396 \\
-2.459\end{array}$ & $\begin{array}{l}-0.899 \\
-1.913 \\
-3.049\end{array}$ & $\begin{array}{l}0.08 \\
0.06\end{array}$ & 26.2 & 1.57 & 25.0 & 1.44 & $4.40 \%$ & 820 & 3 \\
\hline
\end{tabular}


Table XXX: The British Pound against the U.S. Dollar

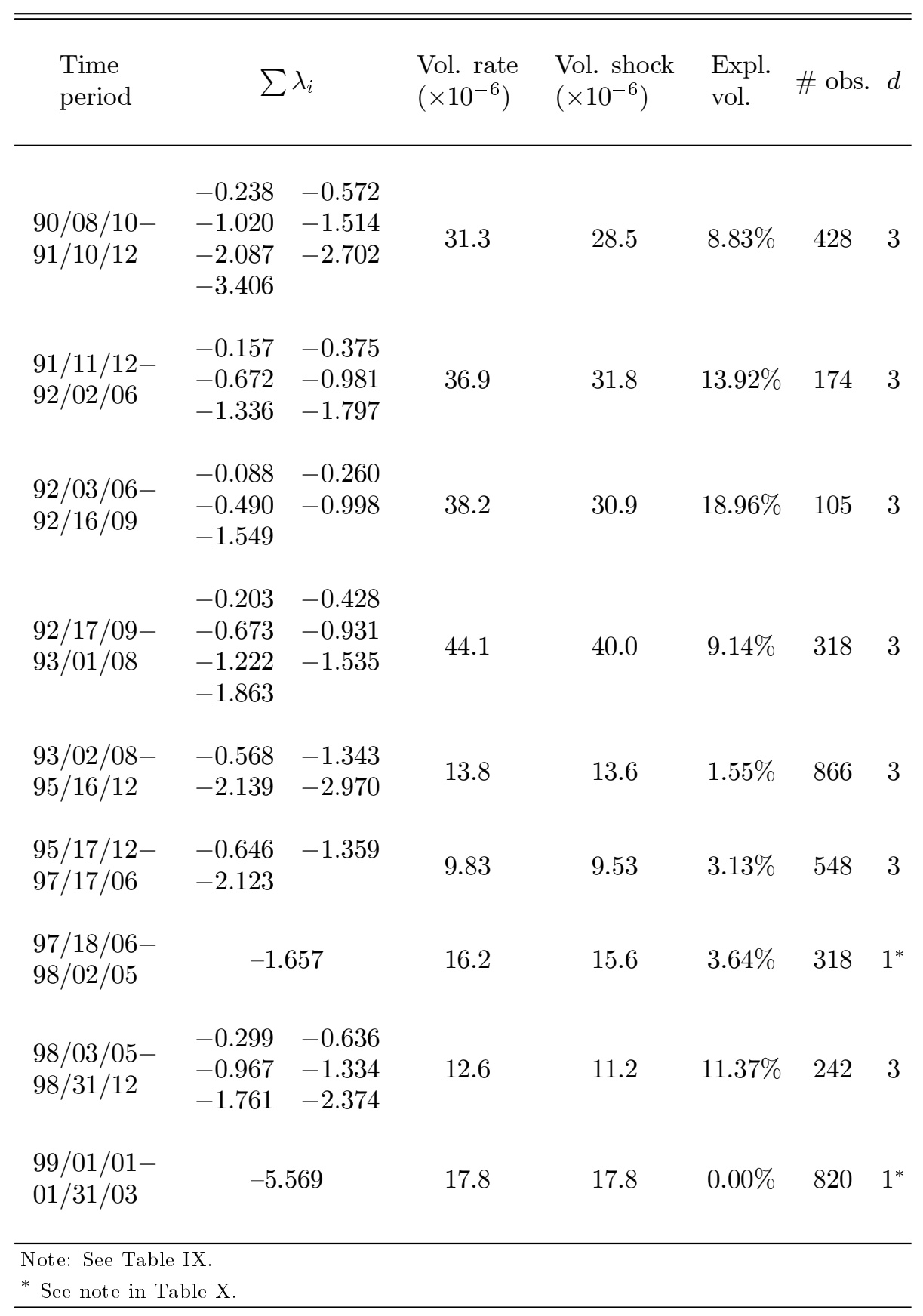


Table XXXI: The Danish Krone against the ECU and the Euro

\begin{tabular}{|c|c|c|c|c|c|c|c|c|c|c|}
\hline $\begin{array}{l}\text { Time } \\
\text { period }\end{array}$ & \multicolumn{2}{|c|}{$\sum \lambda_{i}$} & $\begin{array}{l}s\left(\bar{\lambda}_{1}\right) \\
s(\widetilde{\lambda})\end{array}$ & $\begin{array}{l}\text { Vol. rate } \\
\left(\times 10^{-6}\right)\end{array}$ & $v$ & $\begin{array}{l}\text { Vol. shock } \\
\left(\times 10^{-6}\right)\end{array}$ & $x$ & $\begin{array}{l}\text { Expl. } \\
\text { vol. }\end{array}$ & \# obs. & $d$ \\
\hline $\begin{array}{l}90 / 02 / 01- \\
91 / 10 / 12\end{array}$ & $\begin{array}{l}-0.303 \\
-0.932 \\
-1.623 \\
-2.404\end{array}$ & $\begin{array}{l}-0.610 \\
-1.252 \\
-1.995\end{array}$ & & 6.15 & & 4.78 & & $22.23 \%$ & 707 & 3 \\
\hline $\begin{array}{l}91 / 11 / 12- \\
92 / 02 / 06\end{array}$ & $\begin{array}{l}-0.362 \\
-1.117 \\
-1.990\end{array}$ & $\begin{array}{l}-0.723 \\
-1.544 \\
-2.440\end{array}$ & $\begin{array}{l}6.42 \\
2.56\end{array}$ & 7.06 & 0.97 & 5.19 & 1.00 & $26.45 \%$ & 174 & 3 \\
\hline $\begin{array}{l}92 / 03 / 06- \\
93 / 18 / 05\end{array}$ & $\begin{array}{l}-0.330 \\
-1.172 \\
-2.142 \\
-3.336\end{array}$ & $\begin{array}{l}-0.735 \\
-1.633 \\
-2.681\end{array}$ & $\begin{array}{l}0.61 \\
1.62\end{array}$ & 12.6 & 1.59 & 10.1 & 1.66 & $19.75 \%$ & 349 & 3 \\
\hline $\begin{array}{l}93 / 19 / 05- \\
93 / 01 / 08\end{array}$ & -0.687 & -1.526 & $\begin{array}{l}-82.7 \\
3.52\end{array}$ & 11.1 & 1.15 & 9.31 & 1.55 & $15.95 \%$ & 74 & 3 \\
\hline $\begin{array}{l}93 / 02 / 08- \\
95 / 16 / 12\end{array}$ & -1.740 & -3.579 & $\begin{array}{l}-0.05 \\
0.73\end{array}$ & 4.11 & 0.53 & 3.94 & 0.46 & $4.13 \%$ & 866 & 3 \\
\hline $\begin{array}{l}95 / 17 / 12- \\
97 / 17 / 06\end{array}$ & $\begin{array}{l}-0.458 \\
-1.526 \\
-2.843\end{array}$ & $\begin{array}{l}-0.918 \\
-2.140\end{array}$ & $\begin{array}{l}0.26 \\
0.33\end{array}$ & 3.47 & 1.78 & 3.09 & 1.66 & $10.79 \%$ & 548 & 3 \\
\hline $\begin{array}{l}97 / 18 / 06- \\
98 / 02 / 05\end{array}$ & $\begin{array}{l}-0.280 \\
-0.949 \\
-1.847\end{array}$ & $\begin{array}{l}-0.596 \\
-1.317 \\
-2.388\end{array}$ & $\begin{array}{l}0.94 \\
1.00\end{array}$ & 1.83 & 0.32 & 1.37 & 0.28 & $25.14 \%$ & 318 & 3 \\
\hline $\begin{array}{l}98 / 03 / 05- \\
98 / 31 / 12\end{array}$ & $\begin{array}{l}-0.334 \\
-1.048 \\
-1.814\end{array}$ & $\begin{array}{l}-0.668 \\
-1.424 \\
-2.233\end{array}$ & $\begin{array}{l}0.26 \\
0.31\end{array}$ & 5.23 & 3.24 & 3.52 & 2.79 & $32.76 \%$ & 242 & 3 \\
\hline $\begin{array}{l}99 / 01 / 01- \\
00 / 28 / 09\end{array}$ & $\begin{array}{l}-0.229 \\
-0.789 \\
-1.514\end{array}$ & $\begin{array}{l}-0.460 \\
-1.122 \\
-1.906\end{array}$ & $\begin{array}{l}0.77 \\
0.90\end{array}$ & 5.67 & 0.66 & 3.82 & 0.65 & $32.72 \%$ & 636 & 3 \\
\hline $\begin{array}{l}00 / 29 / 09- \\
01 / 31 / 03\end{array}$ & $\begin{array}{l}-0.309 \\
-1.072 \\
-1.986\end{array}$ & $\begin{array}{l}-0.626 \\
-1.529\end{array}$ & $\begin{array}{l}6.78 \\
3.93\end{array}$ & 3.42 & 0.32 & 1.89 & 0.31 & $44.65 \%$ & 183 & 3 \\
\hline
\end{tabular}


Table XXXII: The Danish Krone against the U.S. Dollar

\begin{tabular}{|c|c|c|c|c|c|c|c|}
\hline $\begin{array}{l}\text { Time } \\
\text { period }\end{array}$ & \multicolumn{2}{|c|}{$\sum \lambda_{i}$} & $\begin{array}{l}\text { Vol. rate } \\
\left(\times 10^{-6}\right)\end{array}$ & $\begin{array}{l}\text { Vol. shock } \\
\left(\times 10^{-6}\right)\end{array}$ & $\begin{array}{l}\text { Expl. } \\
\text { vol. }\end{array}$ & \# obs. & $d$ \\
\hline $\begin{array}{l}90 / 02 / 01- \\
91 / 10 / 12\end{array}$ & $\begin{array}{l}-0.999 \\
-3.191\end{array}$ & -2.045 & 34.3 & 33.7 & $1.83 \%$ & 707 & 3 \\
\hline $\begin{array}{l}91 / 11 / 12- \\
92 / 02 / 06\end{array}$ & $\begin{array}{l}-0.186 \\
-0.684 \\
-1.420 \\
-3.450\end{array}$ & $\begin{array}{l}-0.425 \\
-1.024 \\
-1.835\end{array}$ & 40.7 & 36.5 & $10.27 \%$ & 174 & 3 \\
\hline $\begin{array}{l}92 / 03 / 06- \\
93 / 18 / 05\end{array}$ & $\begin{array}{l}-0.278 \\
-0.902 \\
-1.621 \\
-2.499\end{array}$ & $\begin{array}{l}-0.566 \\
-1.250 \\
-2.042\end{array}$ & 45.6 & 42.8 & $6.17 \%$ & 349 & 2 \\
\hline $\begin{array}{l}93 / 19 / 05- \\
93 / 01 / 08\end{array}$ & $\begin{array}{l}0.007 \\
-0.204 \\
-0.589 \\
-1.138\end{array}$ & $\begin{array}{l}-0.086 \\
-0.367 \\
-0.831\end{array}$ & 34.8 & 25.5 & $26.82 \%$ & 74 & 3 \\
\hline $\begin{array}{l}93 / 02 / 08- \\
95 / 16 / 12\end{array}$ & $\begin{array}{l}-0.361 \\
-1.148 \\
-2.046 \\
-3.659\end{array}$ & $\begin{array}{l}-0.745 \\
-1.586 \\
-2.601\end{array}$ & 24.5 & 23.7 & $3.40 \%$ & 866 & 3 \\
\hline $\begin{array}{l}95 / 17 / 12- \\
97 / 17 / 06\end{array}$ & $\begin{array}{l}-0.362 \\
-1.286 \\
-2.533\end{array}$ & $\begin{array}{l}-0.777 \\
-1.878\end{array}$ & 11.6 & 11.2 & $3.52 \%$ & 548 & 2 \\
\hline $\begin{array}{l}97 / 18 / 06- \\
98 / 02 / 05\end{array}$ & $\begin{array}{l}-0.235 \\
-0.844 \\
-1.572 \\
-2.476\end{array}$ & $\begin{array}{l}-0.525 \\
-1.192 \\
-1.992\end{array}$ & 19.4 & 17.8 & $7.91 \%$ & 318 & 3 \\
\hline $\begin{array}{l}98 / 03 / 05- \\
98 / 31 / 12\end{array}$ & -1.071 & -2.142 & 17.1 & 16.4 & $4.26 \%$ & 242 & 1 \\
\hline $\begin{array}{l}99 / 01 / 01- \\
00 / 28 / 09\end{array}$ & -0.955 & -2.032 & 28.2 & 27.5 & $2.36 \%$ & 636 & 3 \\
\hline $\begin{array}{l}00 / 29 / 09- \\
01 / 31 / 03\end{array}$ & $\begin{array}{l}-0.190 \\
-0.679 \\
-1.336 \\
-2.260\end{array}$ & $\begin{array}{l}-0.419 \\
-0.999 \\
-1.716\end{array}$ & 53.1 & 44.5 & $16.35 \%$ & 183 & 2 \\
\hline
\end{tabular}


Table XXXIII: The Greek Drachma against the ECU and the Euro

\begin{tabular}{|c|c|c|c|c|c|c|c|c|c|c|}
\hline $\begin{array}{l}\text { Time } \\
\text { period }\end{array}$ & \multicolumn{2}{|c|}{$\sum \lambda_{i}$} & $\begin{array}{l}s\left(\bar{\lambda}_{1}\right) \\
s(\widetilde{\lambda})\end{array}$ & $\begin{array}{l}\text { Vol. rate } \\
\left(\times 10^{-6}\right)\end{array}$ & $v$ & $\begin{array}{l}\text { Vol. shock } \\
\left(\times 10^{-6}\right)\end{array}$ & $x$ & $\begin{array}{l}\text { Expl. } \\
\text { vol. }\end{array}$ & \# obs & $d$ \\
\hline $\begin{array}{l}90 / 02 / 01- \\
91 / 10 / 12\end{array}$ & $\begin{array}{l}-0.422 \\
-1.292 \\
-2.245\end{array}$ & $\begin{array}{l}-0.847 \\
-1.741 \\
-2.748\end{array}$ & & 8.55 & & 6.61 & & $22.71 \%$ & 707 & 3 \\
\hline $\begin{array}{l}91 / 11 / 12- \\
92 / 02 / 06\end{array}$ & $\begin{array}{l}-0.535 \\
-1.963\end{array}$ & $\begin{array}{l}-1.157 \\
-2.855\end{array}$ & $\begin{array}{l}2.86 \\
2.71\end{array}$ & 11.2 & 1.32 & 7.92 & 1.33 & $29.46 \%$ & 174 & 3 \\
\hline $\begin{array}{l}92 / 03 / 06- \\
93 / 01 / 08\end{array}$ & $\begin{array}{l}-0.297 \\
-0.920 \\
-1.599 \\
-2.374\end{array}$ & $\begin{array}{l}-0.594 \\
-1.245 \\
-1.953\end{array}$ & $\begin{array}{l}0.10 \\
0.12\end{array}$ & 15.6 & 1.18 & 13.1 & 1.27 & $16.28 \%$ & 424 & 1 \\
\hline $\begin{array}{l}93 / 02 / 08- \\
95 / 16 / 12\end{array}$ & $\begin{array}{l}-0.404 \\
-1.298 \\
-2.506\end{array}$ & $\begin{array}{l}-0.833 \\
-1.879\end{array}$ & $\begin{array}{l}3.72 \\
3.43\end{array}$ & 8.71 & 1.04 & 7.54 & 1.06 & $13.38 \%$ & 866 & 2 \\
\hline $\begin{array}{l}95 / 17 / 12- \\
97 / 17 / 06\end{array}$ & $\begin{array}{l}-0.339 \\
-1.073 \\
-1.874 \\
-3.030\end{array}$ & $\begin{array}{l}-0.698 \\
-1.469 \\
-2.290\end{array}$ & $\begin{array}{l}1.43 \\
1.17\end{array}$ & 3.37 & 0.87 & 2.90 & 0.89 & $14.11 \%$ & 548 & 3 \\
\hline $\begin{array}{l}97 / 18 / 06- \\
98 / 02 / 05\end{array}$ & $\begin{array}{l}-0.257 \\
-3.060\end{array}$ & -1.607 & $\begin{array}{l}0.11 \\
0.56\end{array}$ & 52.7 & 2.28 & 36.4 & 1.81 & $30.88 \%$ & 318 & 3 \\
\hline $\begin{array}{l}98 / 03 / 05- \\
98 / 31 / 12\end{array}$ & $\begin{array}{l}-0.222 \\
-0.795 \\
-1.510 \\
-2.345\end{array}$ & $\begin{array}{l}-0.487 \\
-1.132 \\
-1.907\end{array}$ & $\begin{array}{l}4.31 \\
1.17\end{array}$ & 12.4 & 0.63 & 10.3 & 0.80 & $16.93 \%$ & 242 & 3 \\
\hline $\begin{array}{l}99 / 01 / 01- \\
00 / 18 / 06\end{array}$ & $\begin{array}{l}-0.705 \\
-2.302 \\
-4.403\end{array}$ & $\begin{array}{l}-1.451 \\
-3.287\end{array}$ & $\begin{array}{l}0.41 \\
0.48\end{array}$ & 0.974 & 0.07 & 0.940 & 0.07 & $3.47 \%$ & 534 & 3 \\
\hline $\begin{array}{l}00 / 19 / 06- \\
00 / 31 / 12\end{array}$ & $\begin{array}{l}0.326 \\
-0.403 \\
-1.267 \\
-2.161\end{array}$ & $\begin{array}{l}-0.036 \\
-0.829 \\
-1.704\end{array}$ & $\begin{array}{l}-0.19 \\
0.14\end{array}$ & 1.44 & 1.00 & 0.254 & 0.18 & $82.40 \%$ & 195 & 3 \\
\hline
\end{tabular}


Table XXXIV: The Greek Drachma against the U.S. Dollar

\begin{tabular}{|c|c|c|c|c|c|c|c|}
\hline $\begin{array}{l}\text { Time } \\
\text { period }\end{array}$ & \multicolumn{2}{|c|}{$\sum \lambda_{i}$} & $\begin{array}{l}\text { Vol. rate } \\
\left(\times 10^{-6}\right)\end{array}$ & $\begin{array}{l}\text { Vol. shock } \\
\left(\times 10^{-6}\right)\end{array}$ & $\begin{array}{l}\text { Expl. } \\
\text { vol. }\end{array}$ & \# obs. & $d$ \\
\hline $\begin{array}{l}90 / 02 / 01- \\
91 / 10 / 12\end{array}$ & $\begin{array}{l}-0.379 \\
-1.217 \\
-2.170 \\
-3.290\end{array}$ & $\begin{array}{l}-0.780 \\
-1.673 \\
-2.712\end{array}$ & 34.3 & 32.9 & $4.16 \%$ & 707 & 3 \\
\hline $\begin{array}{l}91 / 11 / 12- \\
92 / 02 / 06\end{array}$ & $\begin{array}{l}-0.168 \\
-0.603 \\
-1.207\end{array}$ & $\begin{array}{l}-0.387 \\
-0.891 \\
-1.624\end{array}$ & 34.1 & 29.7 & $12.87 \%$ & 174 & 2 \\
\hline $\begin{array}{l}92 / 03 / 06- \\
93 / 01 / 08\end{array}$ & $\begin{array}{l}-0.971 \\
-3.258\end{array}$ & -1.988 & 40.2 & 38.8 & $3.44 \%$ & 424 & 3 \\
\hline $\begin{array}{l}93 / 02 / 08- \\
95 / 16 / 12\end{array}$ & $\begin{array}{l}-0.355 \\
-1.208 \\
-2.178 \\
-3.276\end{array}$ & $\begin{array}{l}-0.769 \\
-1.682 \\
-2.705\end{array}$ & 21.6 & 21.0 & $2.77 \%$ & 866 & 3 \\
\hline $\begin{array}{l}95 / 17 / 12- \\
97 / 17 / 06\end{array}$ & $\begin{array}{l}-0.209 \\
-0.706 \\
-1.410 \\
-2.424\end{array}$ & $\begin{array}{l}-0.446 \\
-1.000 \\
-1.890\end{array}$ & 9.62 & 9.03 & $6.16 \%$ & 548 & 3 \\
\hline $\begin{array}{l}97 / 18 / 06- \\
98 / 02 / 05\end{array}$ & & 452 & 65.9 & 62.5 & $5.15 \%$ & 318 & 3 \\
\hline $\begin{array}{l}98 / 03 / 05- \\
98 / 31 / 12\end{array}$ & $\begin{array}{l}-0.291 \\
-1.019 \\
-1.915\end{array}$ & $\begin{array}{l}-0.643 \\
-1.437 \\
-2.455\end{array}$ & 24.6 & 22.2 & $9.77 \%$ & 242 & 3 \\
\hline $\begin{array}{l}99 / 01 / 01- \\
00 / 18 / 06\end{array}$ & & 275 & 28.8 & 28.5 & $1.06 \%$ & 534 & 1 \\
\hline $\begin{array}{l}00 / 19 / 06- \\
00 / 31 / 12\end{array}$ & & 497 & 42.4 & 42.4 & $0.00 \%$ & 195 & $1^{*}$ \\
\hline $\begin{array}{l}01 / 01 / 01- \\
01 / 31 / 03\end{array}$ & $\begin{array}{l}-0.297 \\
-1.184\end{array}$ & $\begin{array}{l}-0.594 \\
-1.774\end{array}$ & 49.3 & 43.5 & $11.81 \%$ & 89 & 1 \\
\hline e: See Table & $x$ & & & & & & \\
\hline
\end{tabular}


Table XXXV: The Swedish Krona against the ECU and the Euro

\begin{tabular}{|c|c|c|c|c|c|c|c|c|c|c|}
\hline $\begin{array}{l}\text { Time } \\
\text { period }\end{array}$ & \multicolumn{2}{|c|}{$\sum \lambda_{i}$} & $\begin{array}{l}s\left(\bar{\lambda}_{1}\right) \\
s(\widetilde{\lambda})\end{array}$ & $\begin{array}{l}\text { Vol. rate } \\
\left(\times 10^{-6}\right)\end{array}$ & $v$ & $\begin{array}{l}\text { Vol. shock } \\
\left(\times 10^{-6}\right)\end{array}$ & $x$ & $\begin{array}{l}\text { Expl. } \\
\text { vol. }\end{array}$ & \# obs. & $d$ \\
\hline $\begin{array}{l}90 / 04 / 01- \\
91 / 10 / 12\end{array}$ & $\begin{array}{l}-0.450 \\
-1.509 \\
-2.716 \\
-4.140\end{array}$ & $\begin{array}{l}-0.959 \\
-2.092 \\
-3.389\end{array}$ & & 11.4 & & 8.30 & & $26.86 \%$ & 705 & 3 \\
\hline $\begin{array}{l}91 / 11 / 12- \\
92 / 02 / 06\end{array}$ & $\begin{array}{l}-0.283 \\
-1.002 \\
-1.915 \\
-2.890\end{array}$ & $\begin{array}{l}-0.601 \\
-1.445 \\
-2.400\end{array}$ & $\begin{array}{l}0.68 \\
0.67\end{array}$ & 6.59 & 0.41 & 4.62 & 0.41 & $29.90 \%$ & 174 & 3 \\
\hline $\begin{array}{l}92 / 03 / 06- \\
92 / 19 / 11\end{array}$ & $\begin{array}{l}-0.254 \\
-1.012 \\
-1.986\end{array}$ & $\begin{array}{l}-0.622 \\
-1.489\end{array}$ & $\begin{array}{l}0.16 \\
0.24\end{array}$ & 17.6 & 1.96 & 12.2 & 1.83 & $30.90 \%$ & 169 & 2 \\
\hline $\begin{array}{l}92 / 20 / 11- \\
93 / 01 / 08\end{array}$ & $\begin{array}{l}-0.209 \\
-0.674 \\
-1.198 \\
-1.848\end{array}$ & $\begin{array}{l}-0.436 \\
-0.930 \\
-1.518\end{array}$ & $\begin{array}{l}5.79 \\
1.68\end{array}$ & 30.0 & 1.91 & 28.2 & 2.69 & $6.09 \%$ & 254 & 3 \\
\hline $\begin{array}{l}93 / 02 / 08- \\
94 / 13 / 10\end{array}$ & -1 & 61 & $\begin{array}{l}2.06 \\
4.52\end{array}$ & 20.6 & 1.16 & 19.8 & 1.13 & $3.56 \%$ & 437 & 3 \\
\hline $\begin{array}{l}94 / 14 / 10- \\
95 / 16 / 12\end{array}$ & $\begin{array}{l}-0.350 \\
-1.130 \\
-2.202\end{array}$ & $\begin{array}{l}-0.708 \\
-1.615 \\
-2.862\end{array}$ & $\begin{array}{l}0.47 \\
0.53\end{array}$ & 19.2 & 1.45 & 18.0 & 1.48 & $6.36 \%$ & 428 & 3 \\
\hline $\begin{array}{l}95 / 17 / 12- \\
97 / 17 / 06\end{array}$ & $\begin{array}{l}-0.607 \\
-2.000\end{array}$ & $\begin{array}{l}-1.262 \\
-2.814\end{array}$ & $\begin{array}{l}0.33 \\
0.34\end{array}$ & 10.7 & 0.72 & 10.5 & 0.72 & $2.44 \%$ & 548 & 3 \\
\hline $\begin{array}{l}97 / 18 / 06- \\
98 / 02 / 05\end{array}$ & $\begin{array}{l}-0.596 \\
-2.378\end{array}$ & -1.250 & $\begin{array}{l}7.66 \\
5.81\end{array}$ & 7.48 & 0.51 & 7.10 & 0.52 & $5.08 \%$ & 318 & 3 \\
\hline $\begin{array}{l}98 / 03 / 05- \\
98 / 31 / 12\end{array}$ & $\begin{array}{l}-0.435 \\
-1.473 \\
-2.708\end{array}$ & $\begin{array}{l}-0.926 \\
-2.036\end{array}$ & $\begin{array}{l}0.19 \\
0.24\end{array}$ & 22.6 & 2.06 & 21.8 & 2.11 & $3.62 \%$ & 242 & 3 \\
\hline $\begin{array}{l}99 / 01 / 01- \\
01 / 31 / 03\end{array}$ & $\begin{array}{l}-0.365 \\
-1.136 \\
-2.018\end{array}$ & $\begin{array}{l}-0.745 \\
-1.535 \\
-2.514\end{array}$ & $\begin{array}{l}2.88 \\
2.48\end{array}$ & 9.73 & 0.39 & 9.47 & 0.37 & $2.63 \%$ & 820 & 2 \\
\hline
\end{tabular}


Table XXXVI: The Swedish Krona against the U.S. Dollar

\begin{tabular}{|c|c|c|c|c|c|c|c|}
\hline $\begin{array}{l}\text { Time } \\
\text { period }\end{array}$ & \multicolumn{2}{|c|}{$\sum \lambda_{i}$} & $\begin{array}{l}\text { Vol. rate } \\
\left(\times 10^{-6}\right)\end{array}$ & $\begin{array}{l}\text { Vol. shock } \\
\left(\times 10^{-6}\right)\end{array}$ & $\begin{array}{l}\text { Expl. } \\
\text { vol. }\end{array}$ & \multicolumn{2}{|c|}{ \# obs. $d$} \\
\hline $\begin{array}{l}90 / 04 / 01- \\
91 / 10 / 12\end{array}$ & $\begin{array}{l}-0.395 \\
-1.256 \\
-2.250 \\
-3.426\end{array}$ & $\begin{array}{l}-0.816 \\
-1.734 \\
-2.797\end{array}$ & 28.4 & 26.9 & $5.19 \%$ & 705 & 3 \\
\hline $\begin{array}{l}91 / 11 / 12- \\
92 / 02 / 06\end{array}$ & $\begin{array}{l}-0.368 \\
-1.336\end{array}$ & $\begin{array}{l}-0.811 \\
-2.035\end{array}$ & 39.9 & 36.7 & $8.09 \%$ & 174 & 3 \\
\hline $\begin{array}{l}92 / 03 / 06- \\
92 / 19 / 11\end{array}$ & \multicolumn{2}{|c|}{-2.061} & 54.3 & 53.0 & $2.51 \%$ & 169 & 2 \\
\hline $\begin{array}{l}92 / 20 / 11- \\
93 / 01 / 08\end{array}$ & $\begin{array}{l}-0.293 \\
-1.074 \\
-2.367\end{array}$ & $\begin{array}{l}-0.657 \\
-1.583 \\
-4.881\end{array}$ & 48.4 & 45.6 & $5.75 \%$ & 254 & 3 \\
\hline $\begin{array}{l}93 / 02 / 08- \\
94 / 13 / 10\end{array}$ & -1.337 & -2.674 & 28.7 & 28.4 & $1.16 \%$ & 437 & 1 \\
\hline $\begin{array}{l}94 / 14 / 10- \\
95 / 16 / 12\end{array}$ & $\begin{array}{l}-0.508 \\
-1.638 \\
-3.072\end{array}$ & $\begin{array}{l}-1.031 \\
-2.302\end{array}$ & 18.4 & 17.5 & $4.87 \%$ & 428 & 2 \\
\hline $\begin{array}{l}95 / 17 / 12- \\
97 / 17 / 06\end{array}$ & \multicolumn{2}{|c|}{-2.654} & 14.3 & 14.2 & $0.50 \%$ & 548 & 1 \\
\hline $\begin{array}{l}97 / 18 / 06- \\
98 / 02 / 05\end{array}$ & $\begin{array}{l}-0.340 \\
-1.214 \\
-2.395\end{array}$ & $\begin{array}{l}-0.738 \\
-1.763 \\
-3.086\end{array}$ & 19.6 & 18.5 & $5.39 \%$ & 318 & 3 \\
\hline $\begin{array}{l}98 / 03 / 05- \\
98 / 31 / 12\end{array}$ & -1.296 & -2.872 & 28.8 & 26.9 & $6.58 \%$ & 242 & 2 \\
\hline $\begin{array}{l}99 / 01 / 01- \\
01 / 31 / 03\end{array}$ & $\begin{array}{l}-0.377 \\
-1.208 \\
-2.151\end{array}$ & $\begin{array}{l}-0.788 \\
-1.670 \\
-2.689\end{array}$ & 32.0 & 31.2 & $2.74 \%$ & 820 & 2 \\
\hline
\end{tabular}


Table XXXVII: The Norwegian Krone against the ECU and the Euro

\begin{tabular}{|c|c|c|c|c|c|c|c|c|c|c|}
\hline $\begin{array}{l}\text { Time } \\
\text { period }\end{array}$ & \multicolumn{2}{|c|}{$\sum \lambda_{i}$} & $\begin{array}{l}s\left(\bar{\lambda}_{1}\right) \\
s(\widetilde{\lambda})\end{array}$ & $\begin{array}{l}\text { Vol. rate } \\
\left(\times 10^{-6}\right)\end{array}$ & $v$ & $\begin{array}{l}\text { Vol. shock } \\
\left(\times 10^{-6}\right)\end{array}$ & $x$ & $\begin{array}{l}\text { Expl. } \\
\text { vol. }\end{array}$ & \multicolumn{2}{|c|}{ \# obs. $d$} \\
\hline $\begin{array}{l}90 / 02 / 01- \\
91 / 10 / 12\end{array}$ & $\begin{array}{l}-0.323 \\
-1.098 \\
-2.036 \\
-3.188\end{array}$ & $\begin{array}{l}-0.653 \\
-1.549 \\
-2.612\end{array}$ & & 5.78 & & 4.81 & & $16.82 \%$ & 707 & 3 \\
\hline $\begin{array}{l}91 / 11 / 12- \\
92 / 02 / 06\end{array}$ & $\begin{array}{l}-0.368 \\
-1.353 \\
-2.587 \\
-4.022\end{array}$ & $\begin{array}{l}-0.820 \\
-1.944 \\
-3.279\end{array}$ & $\begin{array}{l}6.75 \\
5.80\end{array}$ & 8.10 & 1.10 & 5.91 & 1.03 & $27.12 \%$ & 174 & 3 \\
\hline $\begin{array}{l}92 / 03 / 06- \\
92 / 10 / 12\end{array}$ & $\begin{array}{l}-0.477 \\
-1.599\end{array}$ & $\begin{array}{l}-0.955 \\
-2.254\end{array}$ & $\begin{array}{l}0.29 \\
0.28\end{array}$ & 14.9 & 1.25 & 10.4 & 1.12 & $30.35 \%$ & 190 & 3 \\
\hline $\begin{array}{l}92 / 11 / 12- \\
93 / 01 / 08\end{array}$ & $\begin{array}{l}-0.654 \\
-2.469\end{array}$ & -1.327 & $\begin{array}{l}1.42 \\
1.52\end{array}$ & 15.2 & 1.88 & 13.3 & 2.34 & $12.57 \%$ & 233 & 3 \\
\hline $\begin{array}{l}93 / 02 / 08- \\
94 / 28 / 11\end{array}$ & $\begin{array}{l}-0.636 \\
-2.087 \\
-3.735 \\
-5.646\end{array}$ & $\begin{array}{l}-1.332 \\
-2.893 \\
-4.652\end{array}$ & $\begin{array}{l}3.78 \\
3.13\end{array}$ & 3.27 & 0.33 & 2.53 & 0.30 & $22.69 \%$ & 483 & 3 \\
\hline $\begin{array}{l}94 / 29 / 11- \\
95 / 16 / 12\end{array}$ & $\begin{array}{l}-0.276 \\
-0.856 \\
-1.547\end{array}$ & $\begin{array}{l}-0.554 \\
-1.185\end{array}$ & $\begin{array}{l}0.39 \\
0.38\end{array}$ & 4.43 & 1.06 & 3.98 & 1.27 & $10.20 \%$ & 382 & 3 \\
\hline $\begin{array}{l}95 / 17 / 12- \\
97 / 17 / 06\end{array}$ & $\begin{array}{l}-0.246 \\
-0.775 \\
-1.387 \\
-2.147\end{array}$ & $\begin{array}{l}-0.497 \\
-1.070 \\
-1.752\end{array}$ & $\begin{array}{l}0.95 \\
1.01\end{array}$ & 7.69 & 3.42 & 7.34 & 3.55 & $4.57 \%$ & 548 & 3 \\
\hline $\begin{array}{l}97 / 18 / 06- \\
98 / 02 / 05\end{array}$ & $\begin{array}{l}-0.224 \\
-0.772 \\
-1.488 \\
-2.423\end{array}$ & $\begin{array}{l}-0.488 \\
-1.095 \\
-1.934\end{array}$ & $\begin{array}{l}0.28 \\
0.40\end{array}$ & 6.34 & 0.55 & 5.86 & 0.53 & $7.52 \%$ & 318 & 2 \\
\hline $\begin{array}{l}98 / 03 / 05- \\
98 / 31 / 12\end{array}$ & -2 & & $\begin{array}{l}13.4 \\
7.74\end{array}$ & 23.5 & 2.33 & 22.2 & 2.44 & $5.76 \%$ & 242 & 2 \\
\hline $\begin{array}{l}99 / 01 / 01- \\
01 / 31 / 03\end{array}$ & $\begin{array}{l}-0.381 \\
-1.256 \\
-2.260 \\
-3.427\end{array}$ & $\begin{array}{l}-0.799 \\
-1.744 \\
-2.825\end{array}$ & $\begin{array}{l}0.41 \\
0.43\end{array}$ & 9.29 & 0.46 & 8.99 & 0.46 & $3.22 \%$ & 820 & 3 \\
\hline
\end{tabular}


Table XXXVIII: The Norwegian Krone against the U.S. Dollar

\begin{tabular}{|c|c|c|c|c|c|c|c|}
\hline $\begin{array}{l}\text { Time } \\
\text { period }\end{array}$ & \multicolumn{2}{|c|}{$\sum \lambda_{i}$} & $\begin{array}{l}\text { Vol. rate } \\
\left(\times 10^{-6}\right)\end{array}$ & $\begin{array}{l}\text { Vol. shock } \\
\left(\times 10^{-6}\right)\end{array}$ & $\begin{array}{l}\text { Expl. } \\
\text { vol. }\end{array}$ & \# obs. & $d$ \\
\hline $\begin{array}{l}90 / 02 / 01- \\
91 / 10 / 12\end{array}$ & -1.492 & -3.187 & 31.3 & 30.6 & $2.15 \%$ & 707 & 3 \\
\hline $\begin{array}{l}91 / 11 / 12- \\
92 / 02 / 06\end{array}$ & $\begin{array}{l}-0.252 \\
-0.831 \\
-1.595\end{array}$ & $\begin{array}{l}-0.533 \\
-1.181 \\
-2.081\end{array}$ & 39.7 & 36.5 & $8.07 \%$ & 174 & 2 \\
\hline $\begin{array}{l}92 / 03 / 06- \\
92 / 10 / 12\end{array}$ & -1.108 & -2.453 & 58.6 & 57.2 & $2.43 \%$ & 190 & $2^{*}$ \\
\hline $\begin{array}{l}92 / 11 / 12- \\
93 / 01 / 08\end{array}$ & -1.072 & -2.352 & 31.8 & 31.3 & $1.43 \%$ & 233 & $1^{*}$ \\
\hline $\begin{array}{l}93 / 02 / 08- \\
94 / 28 / 11\end{array}$ & $\begin{array}{l}-0.276 \\
-0.929 \\
-1.672 \\
-2.580\end{array}$ & $\begin{array}{l}-0.600 \\
-1.279 \\
-2.109\end{array}$ & 21.0 & 20.0 & $4.78 \%$ & 483 & 3 \\
\hline $\begin{array}{l}94 / 29 / 11- \\
95 / 16 / 12\end{array}$ & $\begin{array}{l}-0.311 \\
-1.004 \\
-1.790\end{array}$ & $\begin{array}{l}-0.644 \\
-1.375 \\
-2.255\end{array}$ & 26.8 & 24.8 & $7.64 \%$ & 382 & 3 \\
\hline $\begin{array}{l}95 / 17 / 12- \\
97 / 17 / 06\end{array}$ & $\begin{array}{l}-0.293 \\
-0.940 \\
-1.694 \\
-2.592\end{array}$ & $\begin{array}{l}-0.610 \\
-1.303 \\
-2.113\end{array}$ & 13.6 & 12.9 & $5.58 \%$ & 548 & 3 \\
\hline $\begin{array}{l}97 / 18 / 06- \\
98 / 02 / 05\end{array}$ & -0.951 & -2.091 & 20.3 & 19.6 & $3.66 \%$ & 318 & 2 \\
\hline $\begin{array}{l}98 / 03 / 05- \\
98 / 31 / 12\end{array}$ & $\begin{array}{l}-0.700 \\
-2.386\end{array}$ & $\begin{array}{l}-1.483 \\
-3.451\end{array}$ & 32.3 & 30.4 & $5.76 \%$ & 242 & 3 \\
\hline $\begin{array}{l}99 / 01 / 01- \\
01 / 31 / 03\end{array}$ & $\begin{array}{l}-0.294 \\
-0.994 \\
-1.899 \\
-3.116\end{array}$ & $\begin{array}{l}-0.625 \\
-1.425 \\
-2.433\end{array}$ & 28.0 & 26.6 & $5.04 \%$ & 820 & 3 \\
\hline $\begin{array}{l}\text { e: See Tabl } \\
\text { ee note in } \mathrm{T}\end{array}$ & & & & & & & \\
\hline
\end{tabular}


Table XXXIX: The Swiss Franc against the ECU and the Euro

\begin{tabular}{|c|c|c|c|c|c|c|c|c|c|c|}
\hline $\begin{array}{l}\text { Time } \\
\text { period }\end{array}$ & \multicolumn{2}{|c|}{$\sum \lambda_{i}$} & $\begin{array}{l}s\left(\bar{\lambda}_{1}\right) \\
s(\widetilde{\lambda})\end{array}$ & $\begin{array}{l}\text { Vol. rate } \\
\left(\times 10^{-6}\right)\end{array}$ & $v$ & $\begin{array}{l}\text { Vol. shock } \\
\left(\times 10^{-6}\right)\end{array}$ & $x$ & $\begin{array}{l}\text { Expl. } \\
\text { vol. }\end{array}$ & \multicolumn{2}{|c|}{ \# obs. $d$} \\
\hline $\begin{array}{l}90 / 02 / 01- \\
91 / 10 / 12\end{array}$ & -1.436 & -2.873 & & 5.53 & & 5.39 & & $2.50 \%$ & 707 & 1 \\
\hline $\begin{array}{l}91 / 11 / 12- \\
92 / 02 / 06\end{array}$ & \multicolumn{2}{|c|}{-1.677} & $\begin{array}{l}10.5 \\
7.26\end{array}$ & 3.59 & 0.46 & 3.47 & 0.50 & $3.48 \%$ & 174 & 1 \\
\hline $\begin{array}{l}92 / 03 / 06- \\
93 / 01 / 08\end{array}$ & $\begin{array}{l}-0.554 \\
-2.040 \\
-3.980\end{array}$ & $\begin{array}{l}-1.228 \\
-2.950\end{array}$ & $\begin{array}{l}0.05 \\
0.09\end{array}$ & 11.3 & 2.93 & 9.90 & 2.46 & $12.23 \%$ & 424 & 3 \\
\hline $\begin{array}{l}93 / 02 / 08- \\
95 / 16 / 12\end{array}$ & $\begin{array}{l}-0.337 \\
-1.072 \\
-1.889 \\
-2.812\end{array}$ & $\begin{array}{l}-0.690 \\
-1.473 \\
-2.332\end{array}$ & $\begin{array}{l}0.87 \\
0.74\end{array}$ & 5.74 & 0.76 & 5.55 & 0.82 & $3.35 \%$ & 866 & 2 \\
\hline $\begin{array}{l}95 / 17 / 12- \\
97 / 17 / 06\end{array}$ & \multicolumn{2}{|c|}{-2.443} & $\begin{array}{l}11.3 \\
10.3\end{array}$ & 5.84 & 1.83 & 5.80 & 1.89 & $0.75 \%$ & 548 & 1 \\
\hline $\begin{array}{l}97 / 18 / 06- \\
98 / 02 / 05\end{array}$ & $\begin{array}{l}-0.405 \\
-1.293 \\
-2.379\end{array}$ & $\begin{array}{l}-0.849 \\
-1.807 \\
-3.038\end{array}$ & $\begin{array}{l}0.33 \\
0.29\end{array}$ & 6.91 & 0.95 & 6.49 & 0.97 & $6.09 \%$ & 318 & 2 \\
\hline $\begin{array}{l}98 / 03 / 05- \\
98 / 31 / 12\end{array}$ & -2.109 & -4.470 & $\begin{array}{l}9.81 \\
9.21\end{array}$ & 7.73 & 0.80 & 6.85 & 0.76 & $11.37 \%$ & 242 & 3 \\
\hline $\begin{array}{l}99 / 01 / 01- \\
01 / 31 / 03\end{array}$ & $\begin{array}{l}-0.455 \\
-1.519 \\
-2.719 \\
-4.347\end{array}$ & $\begin{array}{l}-0.978 \\
-2.089 \\
-3.472\end{array}$ & $\begin{array}{l}0.14 \\
0.19\end{array}$ & 7.06 & 0.93 & 5.49 & 0.76 & $22.23 \%$ & 820 & 3 \\
\hline
\end{tabular}


Table XL: The Swiss Franc against the U.S. Dollar

\begin{tabular}{|c|c|c|c|c|c|c|c|}
\hline $\begin{array}{l}\text { Time } \\
\text { period }\end{array}$ & \multicolumn{2}{|c|}{$\sum \lambda_{i}$} & $\begin{array}{l}\text { Vol. rate } \\
\left(\times 10^{-6}\right)\end{array}$ & $\begin{array}{l}\text { Vol. shock } \\
\left(\times 10^{-6}\right)\end{array}$ & $\begin{array}{l}\text { Expl. } \\
\text { vol. }\end{array}$ & \# obs. & $d$ \\
\hline $\begin{array}{l}90 / 02 / 01- \\
91 / 10 / 12\end{array}$ & \multicolumn{2}{|c|}{-2.292} & 33.6 & 33.2 & $1.02 \%$ & 707 & 1 \\
\hline $\begin{array}{l}91 / 11 / 12- \\
92 / 02 / 06\end{array}$ & $\begin{array}{l}-0.255 \\
-0.896 \\
-1.692\end{array}$ & $\begin{array}{l}-0.561 \\
-1.241 \\
-2.210\end{array}$ & 47.7 & 42.9 & $10.04 \%$ & 174 & 2 \\
\hline $\begin{array}{l}92 / 03 / 06- \\
93 / 01 / 08\end{array}$ & -1.766 & -3.918 & 51.2 & 49.7 & $2.91 \%$ & 424 & 3 \\
\hline $\begin{array}{l}93 / 02 / 08- \\
95 / 16 / 12\end{array}$ & -1.231 & -2.688 & 34.3 & 34.0 & $0.86 \%$ & 866 & 1 \\
\hline $\begin{array}{l}95 / 17 / 12- \\
97 / 17 / 06\end{array}$ & $\begin{array}{l}-0.791 \\
-2.376\end{array}$ & -1.582 & 19.1 & 18.8 & $1.65 \%$ & 548 & 1 \\
\hline $\begin{array}{l}97 / 18 / 06- \\
98 / 02 / 05\end{array}$ & $\begin{array}{l}-0.392 \\
-1.428 \\
-2.711\end{array}$ & $\begin{array}{l}-0.864 \\
-2.026 \\
-3.442\end{array}$ & 23.7 & 21.7 & $8.52 \%$ & 318 & 3 \\
\hline $\begin{array}{l}98 / 03 / 05- \\
98 / 31 / 12\end{array}$ & $\begin{array}{l}-0.208 \\
-0.663 \\
-1.230\end{array}$ & $\begin{array}{l}-0.424 \\
-0.927 \\
-1.650\end{array}$ & 33.2 & 30.1 & $9.39 \%$ & 242 & 3 \\
\hline $\begin{array}{l}99 / 01 / 01- \\
01 / 31 / 03\end{array}$ & $\begin{array}{l}-0.320 \\
-1.045 \\
-1.877 \\
-2.880\end{array}$ & $\begin{array}{l}-0.665 \\
-1.451 \\
-2.354\end{array}$ & 32.7 & 31.7 & $2.91 \%$ & 820 & 3 \\
\hline
\end{tabular}

